\title{
Coenzyme Q10 Prevents Senescence and Dysfunction Caused by Oxidative Stress in Vascular Endothelial Cells
}

\author{
Jia Huo $\mathbb{D}^{1,2}$ Zhe Xu, ${ }^{1,3}$ Kazunori Hosoe, ${ }^{4}$ Hiroshi Kubo, ${ }^{4}$ Hiroki Miyahara, ${ }^{1}$ Jian Dai, ${ }^{1}$ \\ Masayuki Mori, ${ }^{1,5}$ Jinko Sawashita, ${ }^{1,4,6}$ and Keiichi Higuchi ${ }^{10}{ }^{1,6}$ \\ ${ }^{1}$ Department of Aging Biology, Institute of Pathogenesis and Disease Prevention, Shinshu University Graduate School of Medicine, \\ Matsumoto 390-8621, Japan \\ ${ }^{2}$ The Third Hospital of Hebei Medical University, Shijiazhuang 050017, China \\ ${ }^{3}$ The First Hospital of Hebei Medical University, Shijiazhuang 050030, China \\ ${ }^{4}$ Supplemental Nutrition Division, Pharma \& Supplemental Nutrition Solutions Vehicle, Kaneka Corporation, \\ Osaka 530-8288, Japan \\ ${ }^{5}$ Department of Advanced Medicine for Heath Promotion, Institute for Biomedical Sciences, Interdisciplinary Cluster for Cutting Edge \\ Research, Shinshu University, Matsumoto 390-8621, Japan \\ ${ }^{6}$ Department of Biological Sciences for Intractable Neurological Diseases, Institute for Biomedical Sciences, Interdisciplinary Cluster \\ for Cutting Edge Research, Shinshu University, Matsumoto 390-8621, Japan
}

Correspondence should be addressed to Keiichi Higuchi; keiichih@shinshu-u.ac.jp

Received 20 December 2017; Revised 20 March 2018; Accepted 12 April 2018; Published 8 July 2018

Academic Editor: Reiko Matsui

Copyright ( 2018 Jia Huo et al. This is an open access article distributed under the Creative Commons Attribution License, which permits unrestricted use, distribution, and reproduction in any medium, provided the original work is properly cited.

Oxidative damage in endothelial cells is proposed to play an important role in endothelial dysfunction and atherogenesis. We previously reported that the reduced form of coenzyme Q10 $\left(\mathrm{CoQ}_{10} \mathrm{H}_{2}\right)$ effectively inhibits oxidative stress and decelerates senescence in senescence-accelerated mice. Here, we treated human umbilical vein endothelial cells (HUVECs) with $\mathrm{H}_{2} \mathrm{O}_{2}$ and investigated the protective effect of $\mathrm{CoQ}_{10} \mathrm{H}_{2}$ against senescence, oxidative damage, and reduction in cellular functions. We found that $\mathrm{CoQ}_{10} \mathrm{H}_{2}$ markedly reduced the number of senescence-associated $\beta$-galactosidase-positive cells and suppressed the expression of senescence-associated secretory phenotype-associated genes in $\mathrm{H}_{2} \mathrm{O}_{2}$-treated $\mathrm{HUVECs}$. Furthermore, CoQ ${ }_{10} \mathrm{H}_{2}$ suppressed the generation of intracellular reactive oxygen species (ROS) but promoted NO production that was accompanied by increased eNOS expression. $\mathrm{CoQ}_{10} \mathrm{H}_{2}$ prevented apoptosis and reductions in mitochondrial function and reduced migration and tube formation activity of $\mathrm{H}_{2} \mathrm{O}_{2}$-treated cells. The present study indicated that $\mathrm{CoQ}_{10} \mathrm{H}_{2}$ protects endothelial cells against senescence by promoting mitochondrial function and thus could delay vascular aging.

\section{Introduction}

Cardiovascular diseases (CVD) continue to be a leading cause of death and disability worldwide [1]. This trend is particularly pronounced among aged populations in many countries. Since CVD mortality rates increase with patient age, the aging process is recognized to be the largest risk factor for the development of CVD [2], especially atherosclerosis [3].
The term senescence, a process encompassing age-related and irreversible reductions in physiological functions and increasing mortality rate, is often used to distinguish these processes from chronological aging. Senescence is complex and involves metabolic changes and destruction of molecular and cellular homeostasis that can eventually lead to organ failure and death [4]. Recent studies in humans and animal models suggest that vascular aging/senescence leads to impaired endothelial functions associated with elevated 
oxidative stress and a proinflammatory phenotype [5]. Senescent cells can activate various types of proinflammatory cytokines, chemokines, growth factors, and proteases, which together form the senescence-associated secretory phenotype (SASP) [6].

Hayflick and Moorhead first described cellular senescence in 1961 when they observed a limited ability of cells to replicate in vitro, which they referred to as replicative senescence [7]. At the cellular level, senescence is a complex pathophysiological process that includes various factors, such as accumulation of DNA damage [8], oxidative stress [9], and activation of signaling pathways involved in the general aging process. Several treatments were subsequently identified that promote cellular senescence and induce the phenotype known as stress-induced premature senescence (SIPS). Reactive oxygen species (ROS) are formed as natural products of metabolism and have important roles in several cellular signaling and metabolic pathways, including mitochondrial oxidative phosphorylation, cell proliferation, and cell cycle arrest [10]. However, massive production of ROS during environmental stresses can damage cellular proteins and nucleic acids, as well as peroxidize lipids, which together can ultimately lead to cell death [11]. Previous research on the relationship between oxidative stress and aging indicated that oxidative stress is the origin of cellular senescence [12]. For example, the oxidative stressor hydrogen peroxide $\left(\mathrm{H}_{2} \mathrm{O}_{2}\right)$ can induce an oxidative environment that rapidly leads to premature senescence [13].

The vascular endothelium comprises a thin layer of endothelium that lines the inner surface of blood vessels. Endothelial cells produce the vasorelaxant nitric oxide (NO) generated by NO synthase in endothelial cells (eNOS) that plays an important role in vasodilation. Aging of vascular endothelium in the elderly induces multifactorial dysfunctions in addition to reduced vasodilation [14] during the development of atherosclerosis, which is more pronounced with age $[15,16]$. Thus, aging and endothelial cell dysfunction are closely related and insights into the mechanisms that are responsible for this dysfunction are important for delaying aging and enhancing the overall health of the elderly population.

Human umbilical vein endothelial cells (HUVECs) originate from the endothelium of human umbilical cord veins. HUVECs are used as a classic model system to study many aspects of endothelial function and disease, such as oxidative stress- and inflammation-related pathways in endothelia under normal and pathological conditions [17].

Coenzyme Q10 $\left(\mathrm{CoQ}_{10}\right)$ is a ubiquitous lipid-soluble molecule found in many eukaryotic cells [18] that is essential for mitochondrial oxidative phosphorylation and electron transport chain activity [19]. With increasing age, CoQ10 concentrations in organisms decrease gradually and this decrease can be accompanied by the onset of physical dysfunction and the emergence of disease [20]. The critical role of $\mathrm{CoQ}_{10}$ in mitochondrial function [21] and its status as a lipid-soluble antioxidant have led to its use in therapeutic applications and clinical trials for CVD treatments [22]. Most $\mathrm{CoQ}_{10}$ in circulation and tissues exists in its reduced form $\left(\mathrm{CoQ}_{10} \mathrm{H}_{2}\right)$, which acts as an antioxidant through its oxidation to an oxidized form $\left(\mathrm{oxCoQ}_{10}\right)$ [23]. In addition, recent studies showed that the nonmitochondrial $\mathrm{CoQ}_{10^{-}}$ forming enzyme in Golgi membranes has specific cardiovascular protective functions that modulate eNOS activity through redox reactions involving $\mathrm{CoQ}_{10}$ [24]. NO synthetized by eNOS is known to be an essential factor for cardiovascular function in vertebrates [25] and prevents the progression of age-related dysfunction in endothelial cells [26]. Our previous studies showed that $\mathrm{CoQ}_{10} \mathrm{H}_{2}$ increases levels of cyclic adenosine monophosphate (cAMP) in tissues and cells and also enhances mitochondrial antioxidant function by activating SIRT1 and PGC- $1 \alpha$ that in turn delays senescence and incidence of related diseases [27]. SIRT1 is recognized as an important deacetylase that is related to increasing eNOS-derived nitric oxide (NO) for prevention of endothelial senescence $[28,29]$. In addition, we found that KKAy mice fed diets supplemented with $\mathrm{CoQ}_{10} \mathrm{H}_{2}$ reduced white adipose tissue and enhanced the function of brown adipose tissue by promoting the expression of SERCA2 and decreasing cytoplasmic $\mathrm{Ca}^{2+}$ levels in liver cells. These mice also had an enhanced fat metabolic rate through inhibition of the CaMKII-MEK1/2-ERK1/2 signaling pathway and increased cAMP levels [30]. In HUVECs, $\mathrm{CoQ}_{10} \mathrm{H}_{2}$ has been reported to have an anti-inflammatory function and to delay SASP acquisition in senescence status by attenuating miR146a expression [31].

Here, our results showed that preincubation of HUVECs with $\mathrm{CoQ}_{10} \mathrm{H}_{2}$ prevented $\mathrm{H}_{2} \mathrm{O}_{2}$-induced premature senescence and ameliorated declines in physiological functions of endothelial cells. This action could be mediated by enhancing mitochondrial and endothelial function via the SIRT1-eNOS pathway and upregulating expression of antioxidant enzymes and decreasing intracellular ROS production.

\section{Materials and Methods}

2.1. Cell Culture. Human umbilical vein endothelial cells (HUVECs) were purchased from the Japanese Cancer Research Resources Bank (http://cellbank.nibiohn.go.jp/ english/). The cells were grown in endothelial growth medium (EGM-2; Lonza Walkersville, MD, USA) at $37^{\circ} \mathrm{C}$ under a humidified atmosphere of $5 \% \mathrm{CO}_{2}$, and the medium was changed every 2 days. HUVECs were passaged when they reached $80 \%$ confluence, and cells from passages $2-8$ were used for all experiments. When HUVECs reached $90 \%$ confluence, the cells were divided into 4 experimental groups: (1) control group: untreated HUVECs; (2) $\mathrm{CoQ}_{10} \mathrm{H}_{2}$ group: cultured HUVECs incubated for 24 hours in medium with $10 \mu \mathrm{M} \mathrm{CoQ}_{10} \mathrm{H}_{2}$ and then cultured for an additional 12 hours in medium lacking $\mathrm{CoQ}_{10} \mathrm{H}_{2}$; (3) $\mathrm{H}_{2} \mathrm{O}_{2}$ group: HUVECs cultured for 24 hours in medium without $\mathrm{CoQ}_{10} \mathrm{H}_{2}$ and cultured for another 12 hours in medium containing $100 \mu \mathrm{M} \mathrm{H}_{2} \mathrm{O}_{2}$ and lacking $\mathrm{CoQ}_{10} \mathrm{H}_{2}$; and (4) $\mathrm{CoQ}_{10} \mathrm{H}_{2}+$ $\mathrm{H}_{2} \mathrm{O}_{2}$ group: $\mathrm{HUVECs}$ cultured for 24 hours in medium with $10 \mu \mathrm{M} \mathrm{CoQ}{ }_{10} \mathrm{H}_{2}$ and then cultured for 12 hours in medium with $100 \mu \mathrm{M} \mathrm{H}_{2} \mathrm{O}_{2}$ and lacking $\mathrm{CoQ}_{10} \mathrm{H}_{2}$. We also incubated HUVECs in medium containing high glucose $(30 \mathrm{mM}$; HG medium) to induce senescence. We pretreated HUVECs with 
$10 \mu \mathrm{M} \mathrm{CoQ}_{10} \mathrm{H}_{2}$ and then cultured for an additional 72 hours in $\mathrm{HG}$ medium.

2.2. Real-Time RT-PCR. HUVECs were collected by scraping and the total RNA was extracted from cells using TRIzol Reagent (Invitrogen, CA) followed by treatment with DNAFree (Applied Biosystems, CA) to remove contaminating DNA. Total RNA was subjected to reverse transcription using an Omniscript RT kit (Applied Biosystems, CA) with random primers (Applied Biosystems, CA). Quantitative real-time RT-PCR analysis was carried out using an ABI PRISM 7500 Sequence Detection System (Applied Biosystems, CA) with SYBR Green (Takara Bio, Tokyo, Japan). Primer sequences are listed in Table S1.

\subsection{Senescence-Associated Galactosidase (SA- $\beta-G a l)$} Staining. After 12 hours incubation in medium with or without $\mathrm{H}_{2} \mathrm{O}_{2}$, or 72 hours incubation in medium with or without HG, HUVECs were washed twice with PBS, fixed for 10 minutes with $10 \%$ formalin at room temperature, and washed twice in PBS. The cells were then incubated at $37^{\circ} \mathrm{C}$ for 12 hours with a staining solution $(40 \mathrm{mM}$ citric acid/sodium phosphate buffer $\mathrm{pH} 6.0,0.5 \mathrm{mg} / \mathrm{mL}$ X-Gal, $5 \mathrm{mM}$ potassium ferrocyanide, $5 \mathrm{mM}$ potassium ferricyanide, $150 \mathrm{mM} \mathrm{NaCl}$, and $2 \mathrm{mM} \mathrm{MgCl}$ ). SA- $\beta$-Gal-positive cells were observed by microscopy, and over 300 cells were counted in three independent fields to calculate the proportion of positive cells.

2.4. Analysis of Apoptosis. Apoptosis was assessed using an Annexin V-FITC Apoptosis Detection kit (Enzo Life Sciences, NW). HUVECs in each experimental group were washed with PBS after 12 hours incubation in medium with or without $\mathrm{H}_{2} \mathrm{O}_{2}$ and then collected by trypsinization. The collected cells were washed in PBS with gentle shaking and resuspended with $195 \mu \mathrm{L}$ of a specific binding buffer containing $5 \mu \mathrm{L}$ annexin V-FITC. After incubation for 10 minutes in the dark at room temperature, the cells were washed in PBS, resuspended in $190 \mu \mathrm{L}$ binding buffer, and then stained with $10 \mu \mathrm{L}$ propidium iodide (PI) $(20 \mu \mathrm{g} / \mathrm{mL})$. Cellular fluorescence was analyzed with a FACSCanto II flow cytometer system (BD Biosciences, $\mathrm{NJ}$ ), and the data were analyzed using BD FACSDiva ${ }^{\mathrm{TM}}$ software. HUVECs were classified as follows: normal healthy cells (Annexin $\mathrm{V}^{-} / \mathrm{PI}^{-}$), early apoptotic cells (Annexin $\mathrm{V}^{+} / \mathrm{PI}^{-}$), late apoptotic cells (Annexin $\mathrm{V}^{+} /$ $\mathrm{PI}^{+}$), and necrotic cells (Annexin $\mathrm{V}^{-} / \mathrm{PI}^{+}$).

2.5. Total Reactive Oxygen Species (ROS) and Superoxide Production. Total ROS and superoxide production in HUVECs was determined using a total ROS/superoxide detection kit (Enzo Life Sciences, NW). HUVECs in each experimental group were washed with PBS after 12 hours incubation in medium with or without $\mathrm{H}_{2} \mathrm{O}_{2}$ and then stained according to the kit manufacturer's instructions. Then, cells were assessed by a FACSCalibur flow cytometer system (BD Biosciences, NJ) using the FL1 and FL2 channels to detect signals from ROS- and superoxide-sensitive reagents, respectively. We set the gate for 4 quadrants such that $>99 \%$ of unstained untreated control HUVECs were grouped in the negative area. Over $89 \%$ of positive control cells (pyocyanin-treated) stained only with Oxidative Stress Detection Reagent (green) were gated into the ROS-positive area, and $>89 \%$ of positive control cells (pyocyanin-treated) stained only with Superoxide Detection Reagent (orange) were gated into the superoxide-positive area. Each analysis was continued until 5000 cells were recorded. The obtained data were analyzed using BD CellQuest ${ }^{\mathrm{TM}}$ Pro software.

2.6. Measurement of Free Nitric Oxide (NO). HUVECs were seeded directly into 12-well plates and after reaching $90 \%$ confluency, they were treated with $\mathrm{CoQ}_{10} \mathrm{H}_{2}$ and $\mathrm{H}_{2} \mathrm{O}_{2}$ as described above. NO production was measured by a ROSID NO Detection kit (Enzo Life Science, NW) on a LSM 5 EXCITER laser scanning microscope (Carl Zeiss Microscopy, Jena Deutschland) according to the manufacturer's instructions and analyzed with LSM Software ZEN 2009.

2.7. Analysis of Mitochondrial Membrane Potential. The probe $5,5^{\prime}, 6,6^{\prime}$-tetrachloro-1, $1^{\prime}, 3,3^{\prime}$-tetraethylbenzimidazolylcarbocyanine iodide (JC-1) was used to measure mitochondrial membrane potential and depolarization in HUVECs. HUVECs were placed in 12-well plates, cultured to $90 \%$ confluence, and treated or not with $\mathrm{CoQ}_{10} \mathrm{H}_{2}$ and $\mathrm{H}_{2} \mathrm{O}_{2}$. Then the HUVECs were stained with a JC-1 Mitochondrial Membrane Potential Detection kit according to the manufacturer's instructions (Biotium Inc., CA). Green fluorescence (JC-1 as a monomer at low membrane potentials) and red fluorescence (JC-1 as "J-aggregates" at higher membrane potentials) were monitored with a LSM 5 laser scanning microscope (Carl Zeiss Microscopy, Jena Deutschland). Mitochondrial depolarization was indicated by a decrease in the red/green fluorescence intensity ratio.

2.8. Migration Assay. A scratch (wound healing) assay was performed to evaluate HUVEC migration activity. Treated HUVECs in 12-well plates were scratched with $200 \mu \mathrm{L}$ pipette tips. At 0 hour and 12 hours after scratching, images were taken under an inverted microscope to assess the ability of the cells to migrate into the wound area. The ratio of wound closure was calculated by analyzing images taken 0 and 12 hours after scratching with an image processing program (NIH ImageJ software, version 1.61) [32].

2.9. Cell Tube Formation Assay. Matrigel Matrix 356237 (Corning Inc., Life Sciences, MA) was coated on 15-well $\mu$ angiogenesis slides at $10 \mu \mathrm{L} /$ well (ibidi GmbH, Planegg, Germany). The coated slides were incubated for 15 minutes at $37^{\circ} \mathrm{C}$. Treated HUVECs $(10,000$ cells/well) were harvested and seeded into the Matrigel-containing wells and incubated for 6 hours at $37^{\circ} \mathrm{C}$ to allow tube formation. The wells were then imaged for capillary-like structures using an inverted microscope (Life Technologies). Quantification of the tubes was performed by taking 4 images of each chamber, which were then analyzed by ImageJ for in vitro angiogenesis [33].

2.10. Determination of Cellular $\mathrm{Ca}^{2+}$. Free cytosolic $\mathrm{Ca}^{2+}$ levels were determined with the fluorescent probe Fluo-3 (Dōjindo Laboratories), and the effect of $\mathrm{CoQ}_{10} \mathrm{H}_{2}$ on $\mathrm{H}_{2} \mathrm{O}_{2}$-induced changes in $\mathrm{Ca}^{2+}$ levels was monitored using real-time laser scanning confocal microscopy. Cells were 
cultivated in $35 \mathrm{~mm}$ plates and treated for 24 hours with vehicle (control) or $10 \mu \mathrm{M} \mathrm{CoQ}{ }_{10} \mathrm{H}_{2}$. The cells were then loaded for 30 minutes with $3 \mu \mathrm{M}$ Fluo-3, and medium was replaced with loading buffer to assess whether the $\mathrm{CoQ}_{10} \mathrm{H}_{2}$ effect was due to $\mathrm{Ca}^{2+}$ entry or release from intracellular stores. Cells were imaged with a LSM 7 laser scanning confocal microscope (Carl Zeiss Microscopy, Jena Deutschland), and the results were analyzed with LSM Software ZEN 2010. The baseline was established within the first minute of recording after which $100 \mu \mathrm{L} \mathrm{H}_{2} \mathrm{O}_{2}$ was added to the plate. Epifluorescence images were then recorded. Results were analyzed with software accompanying the laser scanning confocal microscope. Results show the ratio of averaged profiles versus baseline for each treatment [34].

2.11. Analysis of the Concentration of $\mathrm{CoQ}_{10} \mathrm{H}_{2}$ and oxCoQ $\mathrm{Q}_{10}$. After incubation, cells were washed twice in PBS, pelleted, resuspended at $3 \times 10^{6}$ in $700 \mu \mathrm{L}$ 2-propanol, frozen in acetone in dry ice, and stored on dry ice. For analysis, $150 \mu \mathrm{L}$ of 2-propanol containing an internal standard of ubiquinone- 9 at $100 \mathrm{ng} / \mathrm{mL}$ was added to $200 \mu \mathrm{L}$ of the cell suspension, stirred with a vortex mixer for $30 \mathrm{sec}-$ onds, and centrifuged for 5 minutes at $12,000 \mathrm{rpm}$. The supernatant was diluted 5-fold in 2-propanol:methanol $(4: 5, v / v)$, and $10 \mu \mathrm{L}$ of the diluted solution was injected into a LC/MS/MS system.

$\mathrm{CoQ}_{10} \mathrm{H}_{2}$ and oxCoQ ${ }_{10}$ levels in the cells were determined using a LC/MS/MS method described by RuizJimenez et al. [35] with a minor modification. Briefly, detection and quantification were performed using a QTRAP 5500 LC-MS/MS System (AB SCIEX, Framingham, MA, USA) equipped with a Turbo Ion Spray electrospray ionization (ESI) source and a Prominence UFLC system (Shimadzu, Kyoto, Japan). Chromatographic separation was performed on a YMC-UltraHT Pro C18 column, $50 \mathrm{~mm} \times 2.0 \mathrm{~mm}$ I.D., $2.0 \mu \mathrm{m}$ particle size (YMC, Kyoto, Japan) maintained at $30^{\circ} \mathrm{C}$. The mobile phase was methanol containing $5 \mathrm{mM}$ ammonium formate:2 -propanol:ultrapure water $(50: 47: 3, v / v / v)$ pumped at a rate of $0.5 \mathrm{~mL} / \mathrm{min}$ ute. The run time was 5 minutes per injection. Calibration curves were derived from the peak area ratios (analyte/internal standard) using weighted linear least-squares regression of the peak area ratio versus the concentration of the standards. The limits of quantification of ubiquinol-10 and ubiquinone-10 were both $1.5 \mathrm{ng} / 10^{6}$ cells.

2.12. Statistical Analysis. All data are presented as means \pm SD. Data were analyzed using one-way ANOVA followed by Tukey's test or Student's $t$-test using SPSS for Windows software (version 13.0; SPSS Inc., IL). $P<0.05$ was considered to be statistically significant.

\section{Results}

3.1. Effect of $\mathrm{CoQ}_{10} \mathrm{H}_{2}$ on $\mathrm{H}_{2} \mathrm{O}_{2}$-Induced $\mathrm{SA}-\beta$-Gal Activity and Senescence-Associated Gene Expression. HUVECs were incubated in medium containing different concentrations $(0-30 \mu \mathrm{M})$ of $\mathrm{CoQ}_{10} \mathrm{H}_{2}$ or oxCoQ ${ }_{10}$ for 24 hours, and the expression of SIRT1 mRNA [27] was assessed by RT-PCR
(Figure S1A-D). SIRT1 mRNA levels were the highest with $10 \mu \mathrm{M} \mathrm{CoQ}_{10} \mathrm{H}_{2}$. Next, HUVECs were incubated in medium containing $10 \mu \mathrm{M} \quad \mathrm{CoQ}_{10} \mathrm{H}_{2}$ or $\mathrm{oxCoQ}_{10}$ for different time periods $(0-48 \mathrm{~h})$. Under these conditions, expression levels of SIRT1 mRNA were the highest after 24 hours incubation. Meanwhile, mRNA expression levels of eNOS and plasminogen activator inhibitor-1 (PAI-1) in HUVECs first treated with different concentrations of $\mathrm{H}_{2} \mathrm{O}_{2}(0-100 \mu \mathrm{M})$ for 1 hour decreased and increased, respectively, in a dose-dependent manner (Figure S1E). Cell viability markedly decreased during incubation in medium containing $100 \mu \mathrm{M} \mathrm{H}_{2} \mathrm{O}_{2}$ (0-48 hours), but preincubation with $10 \mu \mathrm{M} \mathrm{CoQ}{ }_{10} \mathrm{H}_{2}$ for 24 hours significantly promoted cell viability at 12 hours (Figure S1F). We used a 24-hour preincubation with $10 \mu \mathrm{M} \mathrm{CoQ}{ }_{10} \mathrm{H}_{2}$ followed by a 12 -hour incubation with $100 \mu \mathrm{M} \mathrm{H}_{2} \mathrm{O}_{2}$ for subsequent experiments. Notably, $10 \mu \mathrm{M}$ is almost the same as the plasma concentration in individuals who take oral CoQ10 supplements [36]. We observed that $\mathrm{H}_{2} \mathrm{O}_{2}$ treatment of HUVECs strongly decreased cell proliferation as evidenced by a reduction in the number of $\mathrm{H}_{2} \mathrm{O}_{2}$-treated cells relative to control group cells per field of vision. This effect could be prevented by preincubation with $\mathrm{CoQ}_{10} \mathrm{H}_{2}$ (Figure S2).

The SA- $\beta$-Gal activity and PAI- 1 mRNA expression rate were detected to examine the senescent phenotype of HUVECs (Figures 1 (a) to $1(\mathrm{c})$ ). After treatment with $\mathrm{H}_{2} \mathrm{O}_{2}$ for 12 hours, about $72 \%$ of the cells were SA- $\beta$-Gal-stain positive in the $\mathrm{H}_{2} \mathrm{O}_{2}$ group but only $33 \%$ of the cells were positive in the $\mathrm{CoQ}_{10} \mathrm{H}_{2}+\mathrm{H}_{2} \mathrm{O}_{2}$ group (Figures 1 (a) and $1(\mathrm{~b})$ ). Increases in the mRNA expression levels of PAI-1 in the $\mathrm{H}_{2} \mathrm{O}_{2}$ group were prevented in the $\mathrm{CoQ}_{10} \mathrm{H}_{2}+\mathrm{H}_{2} \mathrm{O}_{2}$ group (Figure 1(c)). RT-PCR analysis of SASP-related gene expression $\left(P 14, p 16^{I N K 4 a} / C D K N 2 A, P 53, P 21, I L-1 \alpha, I L-1 \beta, I L-6\right.$, TNF- $\alpha, M M P-1, M M P-3$, and $M M P-13)$ showed that most genes, including $p 14, p 16$ (CDKN2A), P53, P21, IL-6, $T N F-\alpha, M M P-1$, and $M M P-3$, had increased expression after treatment with $100 \mu \mathrm{M} \mathrm{H}_{2} \mathrm{O}_{2}$, but these adverse effects of $\mathrm{H}_{2} \mathrm{O}_{2}$ could be rescued upon preincubation with $\mathrm{CoQ}_{10} \mathrm{H}_{2}$ (Figure 1(d)).

3.2. Effect of $\mathrm{CoQ}_{10} \mathrm{H}_{2}$ on $\mathrm{HG}$-Induced $\mathrm{SA}-\beta-\mathrm{Gal}$ Activity and Senescence-Associated Gene Expression. SA- $\beta$-Gal activity was detected to examine the HG-induced senescent phenotype of HUVECs [37, 38] (Figures 2(a) and 2(b)). After treatment with $\mathrm{HG}$ for 72 hours, $\sim 26 \%$ of the cells were SA- $\beta$-Gal-stain positive in the HG group but only $10 \%$ of the cells were positive in the $\mathrm{CoQ}_{10} \mathrm{H}_{2}+\mathrm{HG}$ group. Then, senescence-associated gene expression was detected and the results showed that several genes, including PAI-1and P53, had increased expression after treatment with $30 \mathrm{mM}$ glucose (HG), but the adverse effects of HG could be rescued by preincubation with $\mathrm{CoQ}_{10} \mathrm{H}_{2}$ (Figure 2(c)).

3.3. $\mathrm{CoQ}_{10} \mathrm{H}_{2}$ Prevented $\mathrm{H}_{2} \mathrm{O}_{2}$-Induced Apoptosis and Necrosis. $\mathrm{H}_{2} \mathrm{O}_{2}$ was previously reported to promote endothelial tissue injury by inducing cell apoptosis and necrosis [39]. Here, we explored the effect of $\mathrm{H}_{2} \mathrm{O}_{2}$ on apoptosis and necrosis in HUVECs. Incubation of HUVECs with $\mathrm{H}_{2} \mathrm{O}_{2}$ for 12 hours increased the percentage of apoptosis-positive cells 


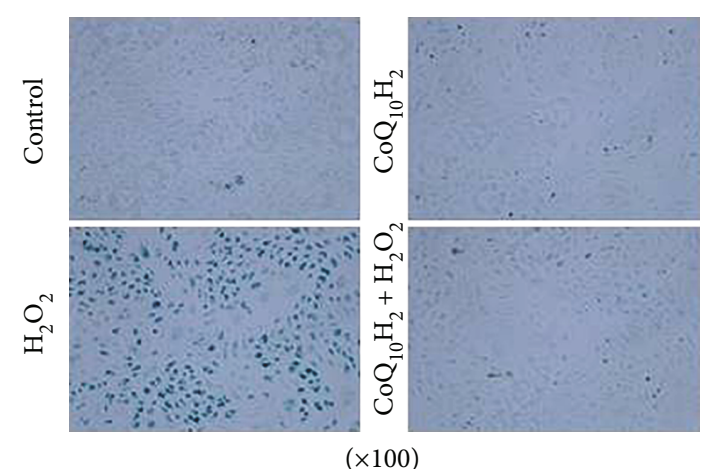

(a)

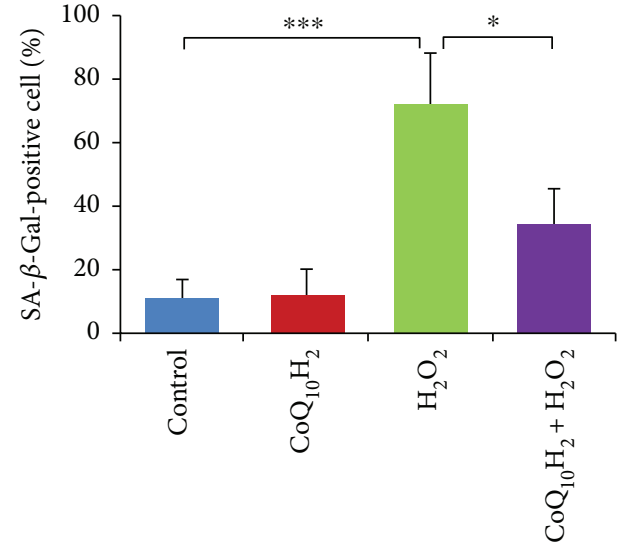

(b)

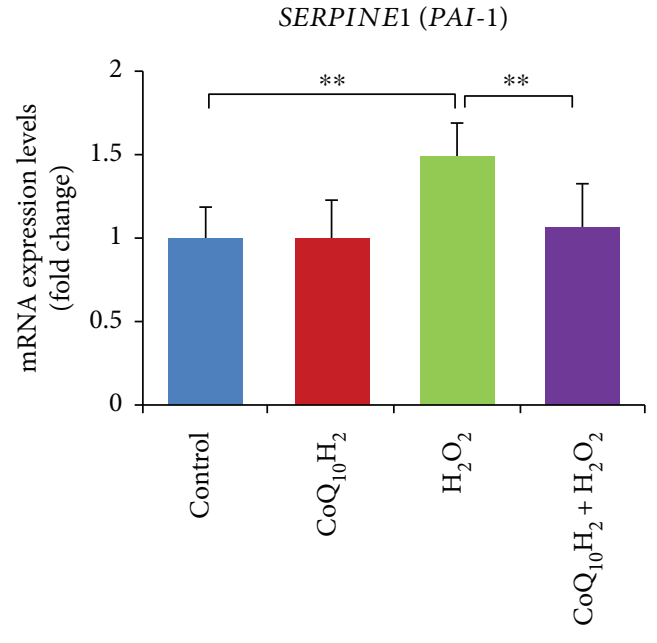

(c)

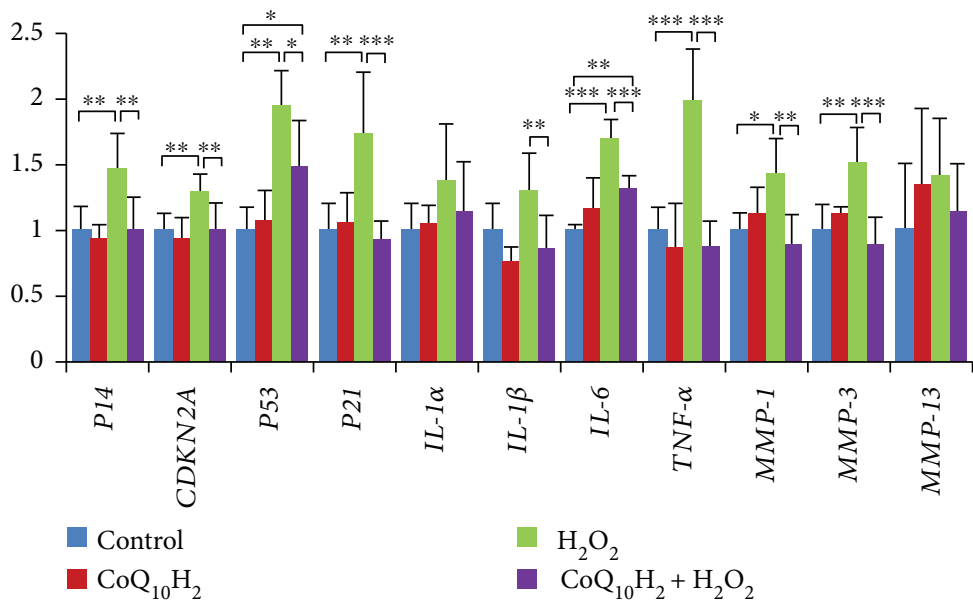

(d)

FIGURE 1: Preincubation with $\mathrm{CoQ}_{10} \mathrm{H}_{2}$ prevented $\mathrm{H}_{2} \mathrm{O}_{2}$-induced senescence of HUVECs. (a) Representative images of SA- $\beta$-Gal-stained cells from each group (control, $\mathrm{CoQ}_{10} \mathrm{H}_{2}, \mathrm{H}_{2} \mathrm{O}_{2}$, and $\mathrm{CoQ}_{10} \mathrm{H}_{2}+\mathrm{H}_{2} \mathrm{O}_{2}$ ). (b) Percentage of SA- $\beta$-Gal-positive cells $(n=4$ ). (c) Expression levels of PAI-1 mRNA $(n=10)$. (d) Expression of genes involved in the senescence-associated secretory phenotype. Histograms show fold change in mRNA level relative to control cells $(n=6-9) .{ }^{*} P<0.05,{ }^{* *} P<0.01$, and ${ }^{* * *} P<0.001$; one-way ANOVA followed by Tukey's test.

from $1.65 \%$ to $6.73 \%$, indicating a modest but significant increase in apoptosis. Meanwhile, the percentage of apoptotic HUVECs preincubated with $\mathrm{CoQ}_{10} \mathrm{H}_{2}$ followed by incubation with $\mathrm{H}_{2} \mathrm{O}_{2}$ was below that for control cells (Figures 3(a) and 3(b)). Treatment with $\mathrm{H}_{2} \mathrm{O}_{2}$ increased the necrosis rate of HUVECs to $9 \%$, but preincubation with $\mathrm{CoQ}_{10} \mathrm{H}_{2}$ could in part rescue $\mathrm{H}_{2} \mathrm{O}_{2}$-induced cell necrosis (Figure 3(c)). Relative to control cells, levels of mRNA for proapoptotic $B A X$ were increased in the $\mathrm{H}_{2} \mathrm{O}_{2}$ group and decreased in the $\mathrm{CoQ}_{10} \mathrm{H}_{2}+\mathrm{H}_{2} \mathrm{O}_{2}$ group. mRNA expression of antiapoptotic BCL-2 decreased in the $\mathrm{H}_{2} \mathrm{O}_{2}$ group, whereas the levels in the $\mathrm{CoQ}_{10} \mathrm{H}_{2}+\mathrm{H}_{2} \mathrm{O}_{2}$ group were similar to control cells and cells incubated with $\mathrm{CoQ}_{10} \mathrm{H}_{2}$ alone (Figure 3(d)). The BAX/BCL-2 ratio dramatically increased in the $\mathrm{H}_{2} \mathrm{O}_{2}$ group but not in the $\mathrm{CoQ}_{10} \mathrm{H}_{2}+\mathrm{H}_{2} \mathrm{O}_{2}$ group (Figure 3(e)). Preincubation with $\mathrm{CoQ}_{10} \mathrm{H}_{2}$ also inhibited an increase in levels of free cytosolic $\mathrm{Ca}^{2+}$ induced by $\mathrm{H}_{2} \mathrm{O}_{2}$ treatment of HUVECs (Figure S3).
3.4. $\mathrm{CoQ}_{10} \mathrm{H}_{2}$ Inhibited $\mathrm{H}_{2} \mathrm{O}_{2}$-Induced ROS Production. Next, we used flow cytometry to examine the effect of $\mathrm{CoQ}_{10} \mathrm{H}_{2}$ and $\mathrm{H}_{2} \mathrm{O}_{2}$ on intracellular ROS production in HUVECs (Figure 4(a)). Treatment with $\mathrm{H}_{2} \mathrm{O}_{2}$ decreased the percentage of ROS/superoxide-negative cells compared with the control group from $64.44 \%$ to $37.48 \%$, whereas 24 hours preincubation with $\mathrm{CoQ}_{10} \mathrm{H}_{2}$ prevented this decrease such that the values were similar to that of control cells. Treatment with $\mathrm{H}_{2} \mathrm{O}_{2}$ induced the production of ROS, which was prevented by preincubation with $\mathrm{CoQ}_{10} \mathrm{H}_{2}$. However, the percentage of superoxide-positive cells and total ROS (tROS) was not affected by $\mathrm{H}_{2} \mathrm{O}_{2}$ treatment (Figures 4(b) and 4(e)), although preincubation with $\mathrm{CoQ}_{10} \mathrm{H}_{2}$ did increase mRNA expression of the ROS scavenger enzyme SOD2 compared with the control group (Figure 4(f)). Meanwhile, treatment with $\mathrm{H}_{2} \mathrm{O}_{2}$ resulted in significant downregulation of SOD2 mRNA expression, which was significantly relieved by preincubation with $\mathrm{CoQ}_{10} \mathrm{H}_{2}$. 


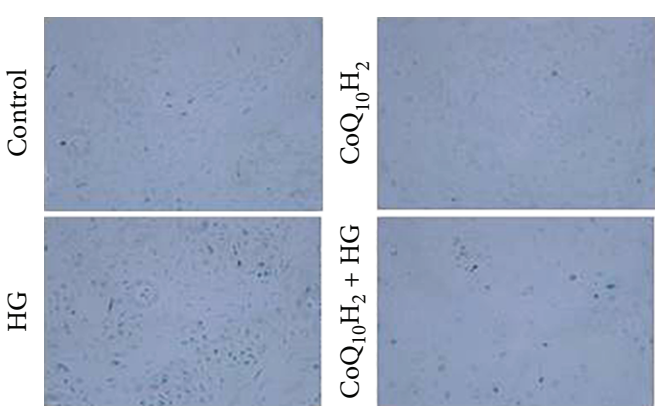

$(\times 100)$

(a)

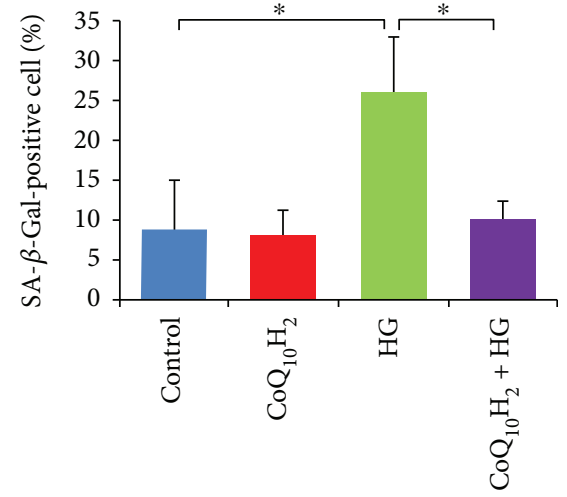

(b)

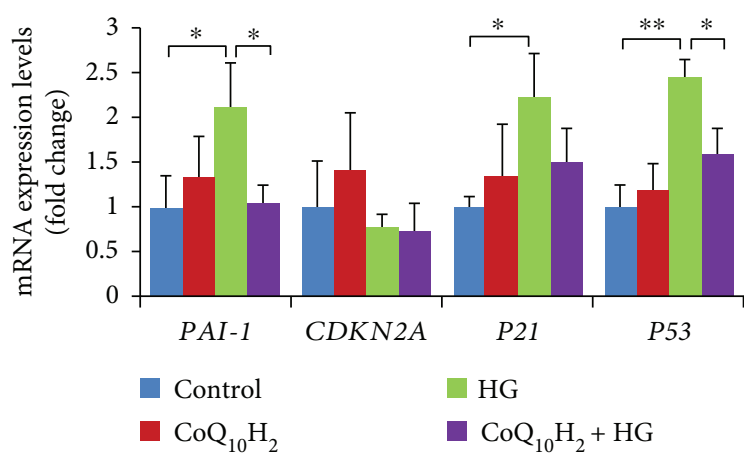

(c)

Figure 2: Preincubation with $\mathrm{CoQ}_{10} \mathrm{H}_{2}$ prevented HG-induced senescence of HUVECs. (a) Representative images of SA- $\beta$-Gal-stained cells from each group (control, $\mathrm{CoQ}_{10} \mathrm{H}_{2}, \mathrm{HG}$, and $\mathrm{CoQ}_{10} \mathrm{H}_{2}+\mathrm{HG}$ ). (b) Percentage of SA- $\beta$-Gal-positive cells $(n=3$ ). (c) Expression levels of senescence-associated mRNA and histograms show fold change in mRNA level relative to control cells $(n=3)$. ${ }^{*} P<0.05$, ${ }^{* *} P<0.01$; oneway ANOVA followed by Tukey's test.

3.5. $\mathrm{CoQ}_{10} \mathrm{H}_{2}$ Prevented a Decrease in NO Production Induced by $\mathrm{H}_{2} \mathrm{O}_{2}$. NO production is an important feature of endothelial cell function. Although laser scanning confocal microscopy showed weaker ( 44\%) NO-specific red fluorescent signals in the cytosol of $\mathrm{H}_{2} \mathrm{O}_{2}$-treated HUVECs compared with the control group, preincubation with $\mathrm{CoQ}_{10} \mathrm{H}_{2}$ increased red fluorescent signals to similar levels as that for the control group (Figures 5(a) and 5(b)) $\mathrm{H}_{2} \mathrm{O}_{2}$ treatment also reduced levels of eNOS mRNA compared with the control group, whereas preincubation with $\mathrm{CoQ}_{10} \mathrm{H}_{2}$ resulted in a significant upregulation of eNOS mRNA compared with the $\mathrm{H}_{2} \mathrm{O}_{2}$-treated group (Figure 5(c)), but treatment with either $\mathrm{CoQ}_{10} \mathrm{H}_{2}$ or $\mathrm{H}_{2} \mathrm{O}_{2}$ did not affect the level of $i N O S$ mRNA compared to the control cells or cells treated with $\mathrm{CoQ}_{10} \mathrm{H}_{2}$ alone (Figure 5(d)).

3.6. Effect of $\mathrm{CoQ}_{10} \mathrm{H}_{2}$ on $\mathrm{H}_{2} \mathrm{O}_{2}$-Dependent Reductions in Mitochondrial Membrane Potential. We next analyzed HUVECs in each group using the mitochondrial membrane potential-sensitive dye JC-1. In control cells and cells that were preincubated with $\mathrm{CoQ}_{10} \mathrm{H}_{2}$, JC-1 aggregates (red fluorescence) in the cytosol were dispersed, whereas in cells exposed to $\mathrm{H}_{2} \mathrm{O}_{2}$, green fluorescence, indicative of the monomeric form of JC-1, was more prominent (Figure 6(a)). Moreover, HUVECs pretreated with $\mathrm{CoQ}_{10} \mathrm{H}_{2}$ displayed a significant upregulation in the ratio of red/green fluorescence relative to the control group, whereas reductions in the ratio of red/green fluorescence seen for $\mathrm{H}_{2} \mathrm{O}_{2}$-treated cells indicated a deterioration in mitochondrial membrane polarization. Preincubation with $\mathrm{CoQ}_{10} \mathrm{H}_{2}$ reduced these $\mathrm{H}_{2} \mathrm{O}_{2}$-dependent decreases in mitochondrial membrane potential (Figure 6(b)). To test whether the $\mathrm{CoQ}_{10} \mathrm{H}_{2}$-dependent preservation of mitochondrial membrane potential was associated with upregulated expression of genes involved in mitochondrial function, we analyzed SIRT1, SIRT3, and PGC-1 $\alpha$ (PPARGC1A) mRNA levels in each group. $\mathrm{H}_{2} \mathrm{O}_{2}$ treatment reduced SIRT1, SIRT3, and PGC-1 $\alpha$ mRNA levels compared with the control group, whereas cells preincubated with $\mathrm{CoQ}_{10} \mathrm{H}_{2}$ prior to $\mathrm{H}_{2} \mathrm{O}_{2}$ treatment showed significant upregulation of SIRT1 and SIRT3 mRNA relative to cells treated with $\mathrm{H}_{2} \mathrm{O}_{2}$ alone (Figure 6(c)).

3.7. $\mathrm{CoQ}_{10} \mathrm{H}_{2}$ Restored Migration Activity and Tube Formation Inhibited by $\mathrm{H}_{2} \mathrm{O}_{2}$ or $\mathrm{HG}$ Treatment. Cell migration and tube formation are involved in angiogenesis, so we next assessed the effect of $\mathrm{CoQ}_{10} \mathrm{H}_{2}$ treatment on impairments of these functions in HUVECs treated with $100 \mu \mathrm{M}$ $\mathrm{H}_{2} \mathrm{O}_{2} \cdot \mathrm{H}_{2} \mathrm{O}_{2}$ treatment of HUVECs strongly decreased the migration activity of these cells as evaluated by a standard cell migration assay (Figures 7(a) and 7(b)). Similarly, treatment with $\mathrm{H}_{2} \mathrm{O}_{2}$ resulted in a $30 \%$ reduction in capillary-like tube 


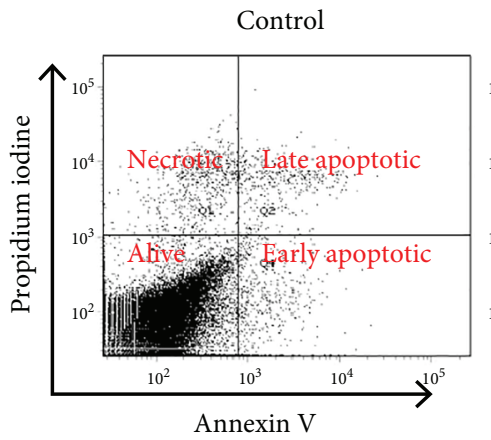

Annexin V
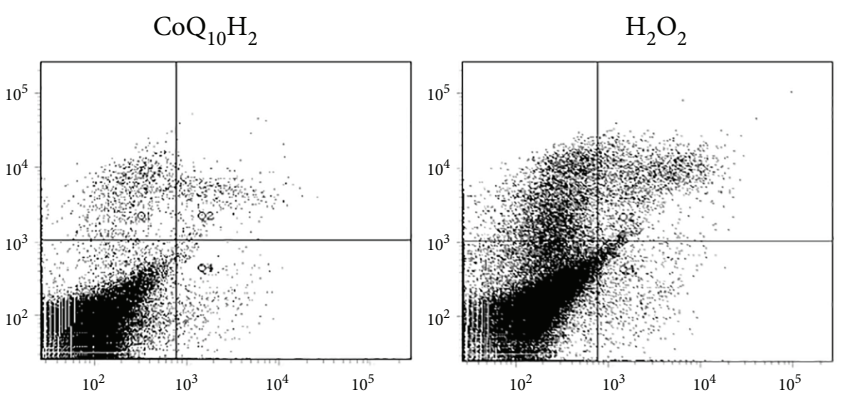

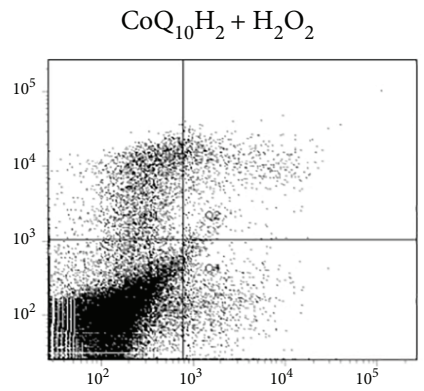

(a)

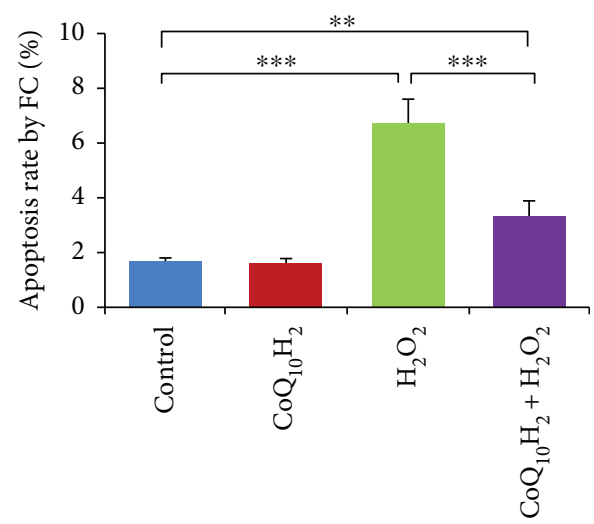

(b)

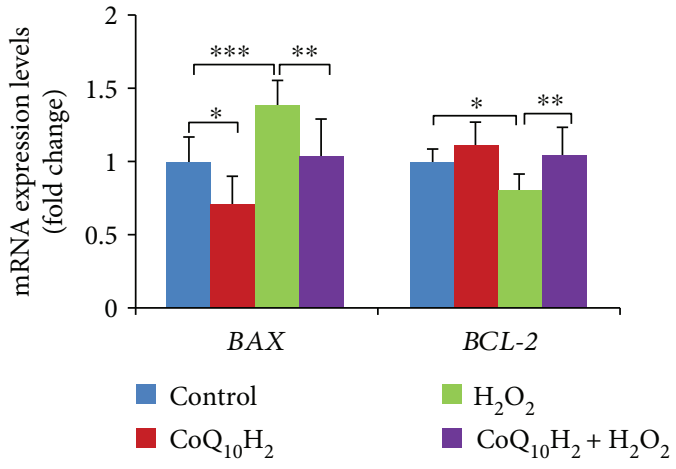

(d)

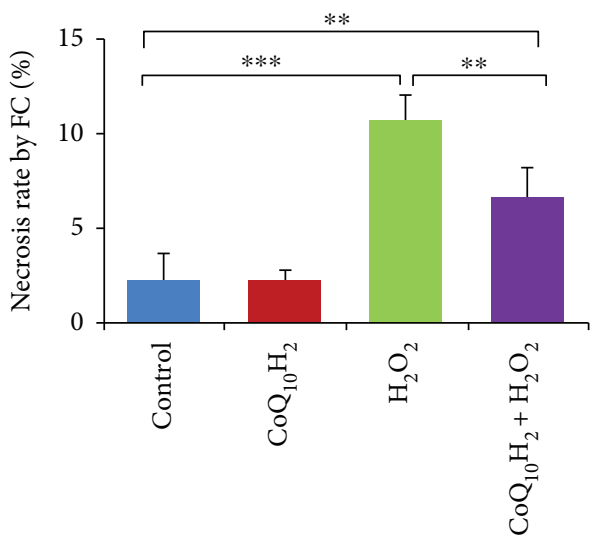

(c)

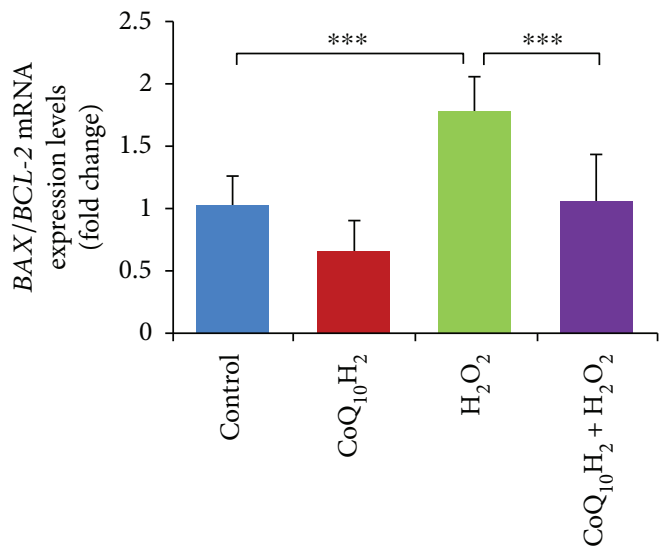

(e)

FIgURE 3: Preincubation with $\mathrm{CoQ}_{10} \mathrm{H}_{2}$ protects HUVECs from $\mathrm{H}_{2} \mathrm{O}_{2}$-induced apoptosis and necrosis. (a) Apoptotic cells were stained with annexin V-FITC and PI and evaluated by flow cytometry. Representative graphs of flow cytometric outputs for each group are shown. (b and c) Bar diagram representing apoptotic and necrotic cell populations $(n=6)$. (d) Analysis of $B A X$ and $B C L-2$ gene expression. Histograms show fold change in mRNA level relative to control cells $(n=9)$. (e) Histograms show $B A X / B C L-2$ ratio $(n=9)$. ${ }^{*} P<0.05,{ }^{* *} P<0.01$, and ${ }^{* * *} P<0.001$; one-way ANOVA followed by Tukey's test.

formation by HUVECs; both of these effects could be prevented by preincubation with $\mathrm{CoQ}_{10} \mathrm{H}_{2}$ (Figures 7 (c) and $7(\mathrm{~d})$ ). We also observed a similar effect of $\mathrm{CoQ}_{10} \mathrm{H}_{2}$ treatment in HUVECs treated with $60 \mu \mathrm{M} \mathrm{H}_{2} \mathrm{O}_{2}$ (Figure S4).

We next assessed the effect of $\mathrm{CoQ}_{10} \mathrm{H}_{2}$ treatment on HG-induced impairment of cell migration function in HUVECs. HG treatment of HUVECs evidently decreased the migration activity of these cells as evaluated by a standard cell migration assay, and this reduction could be rescued by preincubation with $\mathrm{CoQ}_{10} \mathrm{H}_{2}$ (Figures $7(\mathrm{e})$ and $7(\mathrm{f})$ ).

There was no protective effect of incubating cells with $10 \mu \mathrm{M} \mathrm{CoQ}{ }_{10} \mathrm{H}_{2}$ for 24 hours after treatment with $100 \mu \mathrm{M}$ $\mathrm{H}_{2} \mathrm{O}_{2}$ for 12 hours (Figures S5A and B). However, when the incubation time for $100 \mu \mathrm{M} \mathrm{H}_{2} \mathrm{O}_{2}$ was shortened to 3 hours, postincubation with $\mathrm{CoQ}_{10} \mathrm{H}_{2}$ did promote a significant protective effect (Figures S5C and D). 

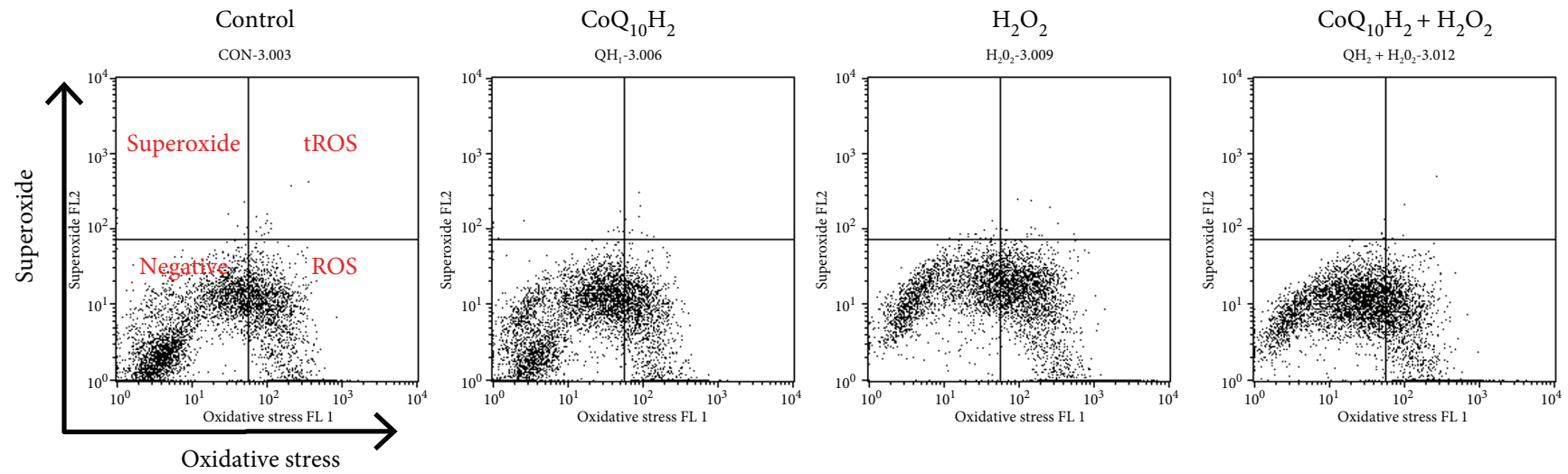

(a)

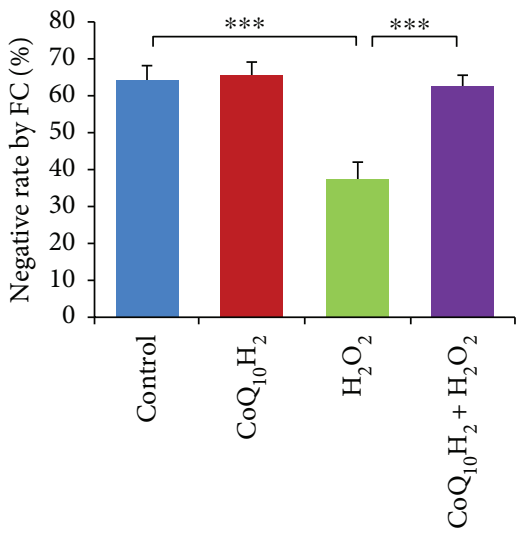

(b)

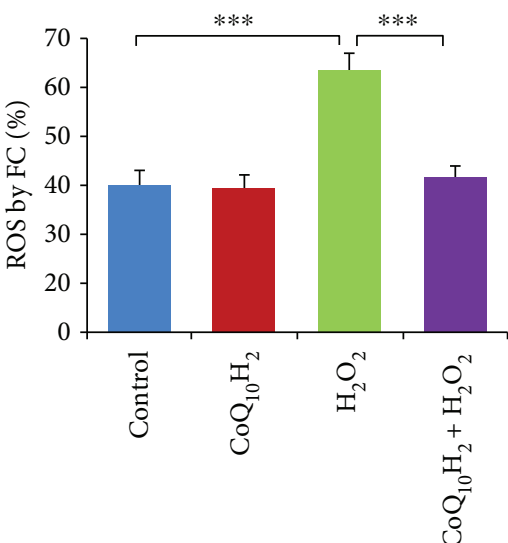

(c)

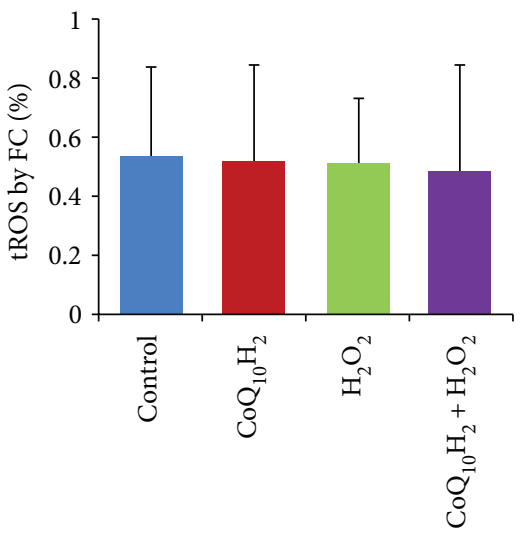

(d)

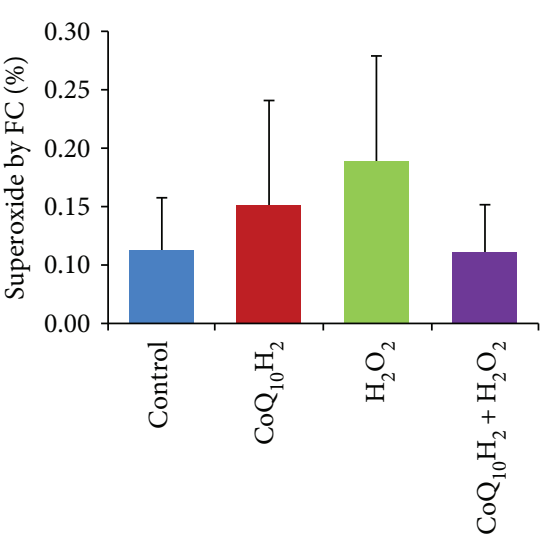

(e)

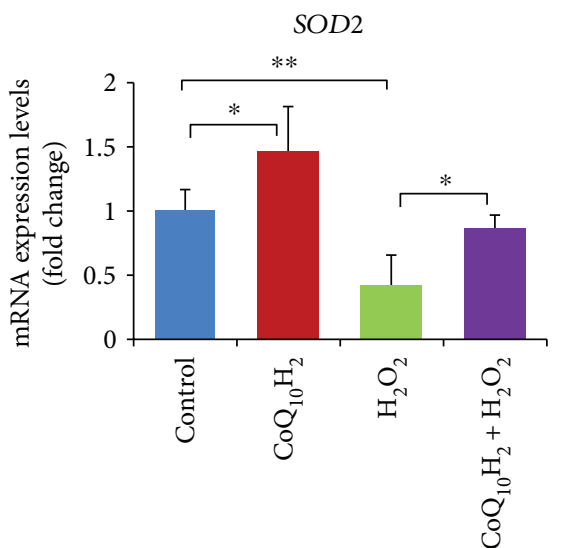

(f)

FIgure 4: Preincubation with $\mathrm{CoQ}_{10} \mathrm{H}_{2}$ decreased $\mathrm{H}_{2} \mathrm{O}_{2}$-induced ROS production in HUVECS. (a) Cells were stained with two color oxidative stress detection reagents for determining ROS production and superoxide levels. Representative pictures of flow cytometry output show the cell population in the four fractions separated by ROS and superoxide $(n=6)$. (b, c, d, and e) Histograms show percentage of cells in negative fractionation, ROS-positive fraction, double-positive fraction, and superoxide-positive fraction. (f) Realtime RT-PCR analysis of SOD2 mRNA expression in cells. Histograms show fold change in mRNA level relative to control cells $(n=6)$. ${ }^{*} P<0.05,{ }^{* *} P<0.01$, and ${ }^{* * *} P<0.001$; one-way ANOVA followed by Tukey's test.

3.8. $\mathrm{CoQ}_{10} \mathrm{H}_{2}$ and oxCoQ ${ }_{10}$ Concentrations in $\mathrm{CoQ}_{10} \mathrm{H}_{2^{-}}$or $\mathrm{H}_{2} \mathrm{O}_{2}$-Treated HUVECs. Incubation of HUVECs in medium containing $10 \mu \mathrm{M} \mathrm{CoQ}{ }_{10} \mathrm{H}_{2}$ led to small and dramatic increases in the intracellular levels of $\mathrm{CoQ}_{10} \mathrm{H}_{2}$ and oxCoQ $\mathrm{C}_{10}$, respectively (Figure $8(\mathrm{a})$ ), and the percentage of $\mathrm{CoQ}_{10} \mathrm{H}_{2}$ relative to total $\mathrm{CoQ}_{10}$ was increased compared with the control group (Figure 8(b)). Interestingly, the concentration of oxCoQ 10 was markedly increased in $\mathrm{H}_{2} \mathrm{O}_{2}$-treated cells compared with the control group. However, $\mathrm{CoQ}_{10} \mathrm{H}_{2}$ preincubation prevented the increase in $\mathrm{oxCoQ}_{10}$ and increased the ratio of $\mathrm{CoQ}_{10} \mathrm{H}_{2}$ to oxCoQ ${ }_{10}\left(\mathrm{CoQ}_{10} \mathrm{H}_{2} / \mathrm{oxCoQ} \mathrm{Co}_{10}\right)$ in the $\mathrm{CoQ}_{10} \mathrm{H}_{2}+\mathrm{H}_{2} \mathrm{O}_{2}$-treated group. 


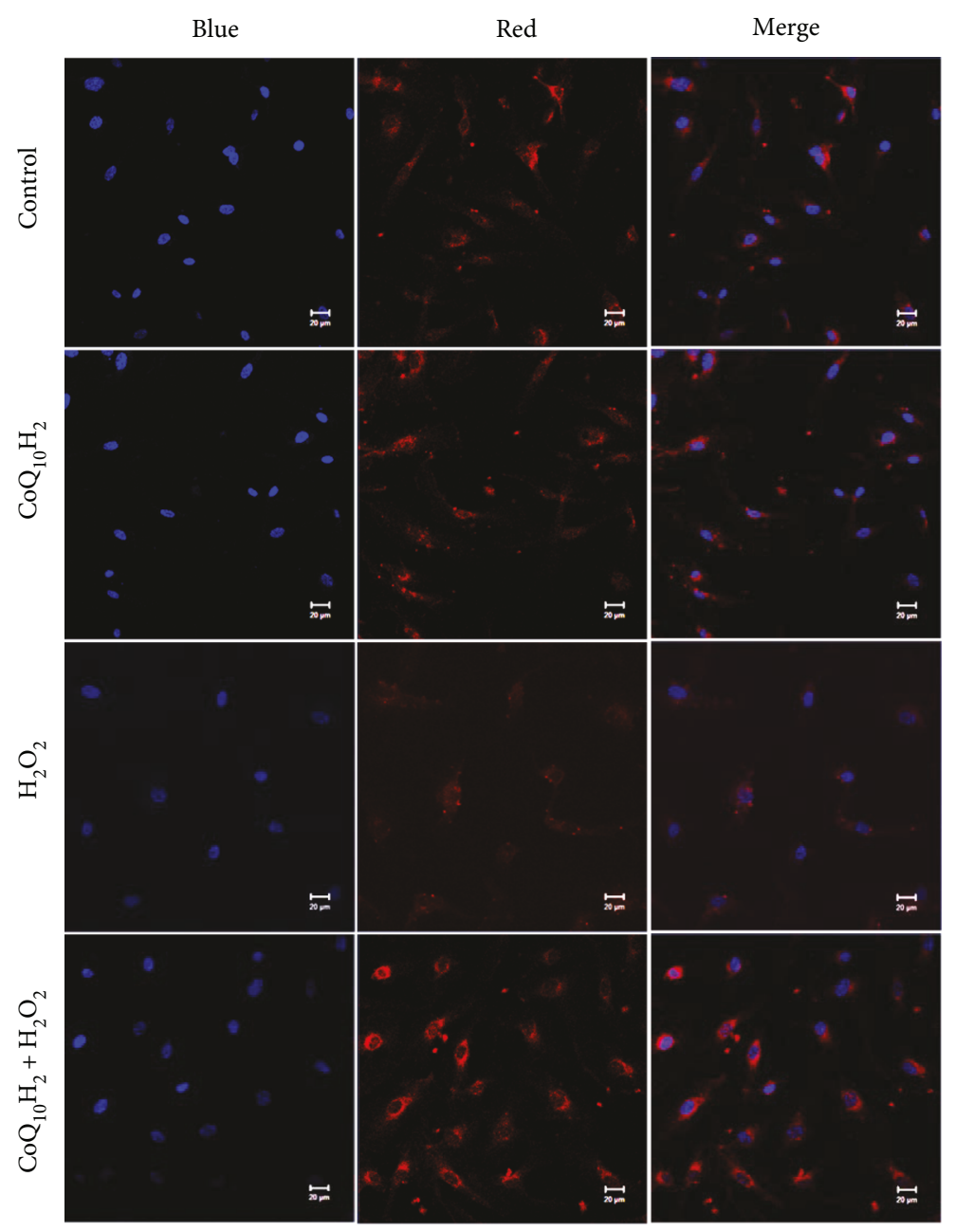

(a)

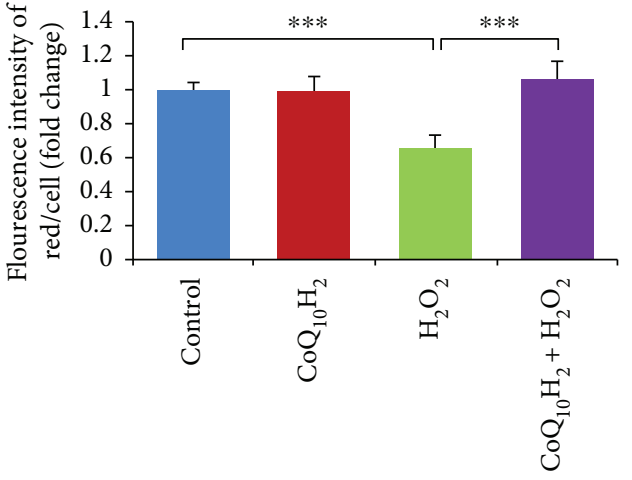

(b)

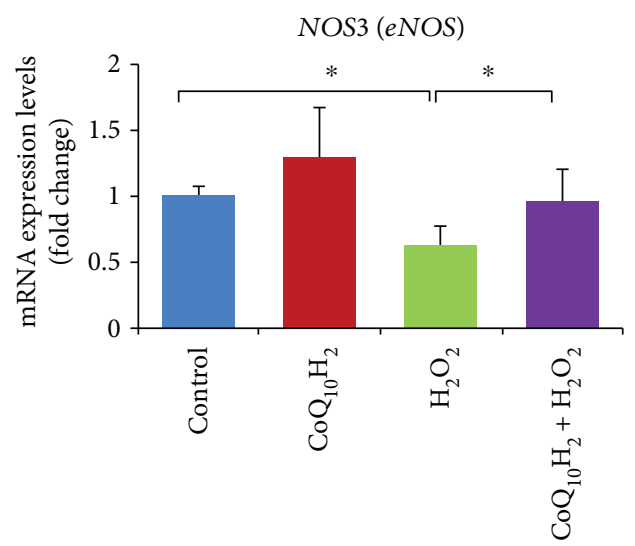

(c)

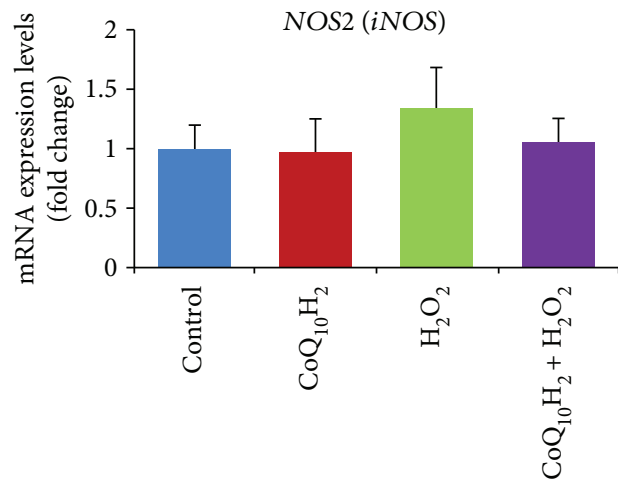

(d)

Figure 5: Preincubation with $\mathrm{CoQ}_{10} \mathrm{H}_{2}$ prevents $\mathrm{H}_{2} \mathrm{O}_{2}$-induced suppression of NO production in HUVECs. (a) Representative images of staining with DAPI (blue) and a NO-specific fluorometric probe (red) acquired using a laser scanning microscope. The two images in each row were captured within the same field and then merged. (b) The intracellular NO level was calculated from the fluorescence intensity in each cell. Histograms show fold change in NO levels relative to control cells $(n=6)$. (c and d) Analysis of $e N O S$ and $i N O S$ gene expression. Histograms show fold change in mRNA level relative to control cells $(n=10)$. ${ }^{*} P<0.05$ and ${ }^{* * *} P<0.001$; one-way ANOVA followed by Tukey's test.

We also analyzed $\mathrm{H}_{2} \mathrm{O}_{2}$-induced changes in $\mathrm{CoQ}_{10} \mathrm{H}_{2}$ and $\mathrm{oxCoQ}_{10}$ concentrations. HUVECs were treated with $100 \mu \mathrm{M} \mathrm{H}_{2} \mathrm{O}_{2}$ for various times (0-24 hours), and cellular $\mathrm{CoQ}_{10} \mathrm{H}_{2}$ and oxCoQ ${ }_{10}$ levels were determined for each time point. The oxCoQ ${ }_{10}$ levels in $\mathrm{H}_{2} \mathrm{O}_{2}$-treated HUVECs increased in a time-dependent manner, while the percentage of $\mathrm{CoQ}_{10} \mathrm{H}_{2}$ in the total coenzyme Q10 (Total $\mathrm{CoQ}_{10}$ ) decreased (Figures S6A and B). The mRNA expressions of the $\mathrm{CoQ}_{10}$ biosynthesis genes $P D S S 2$ and $C O Q_{2}$ were both markedly increased in $\mathrm{H}_{2} \mathrm{O}_{2}$-treated HUVECs after 12 hours compared with the 0-hour group (Figure S6C). The cell number and protein concentration of HUVECs per culture flask were decreased for the 12-hour group relative to the 0-hour group, but the changes were not significant (Figure S6D).

\section{Discussion}

The main findings of our study are that $\mathrm{CoQ}_{10} \mathrm{H}_{2}$ prevented functional damage of endothelial cells that accompany 


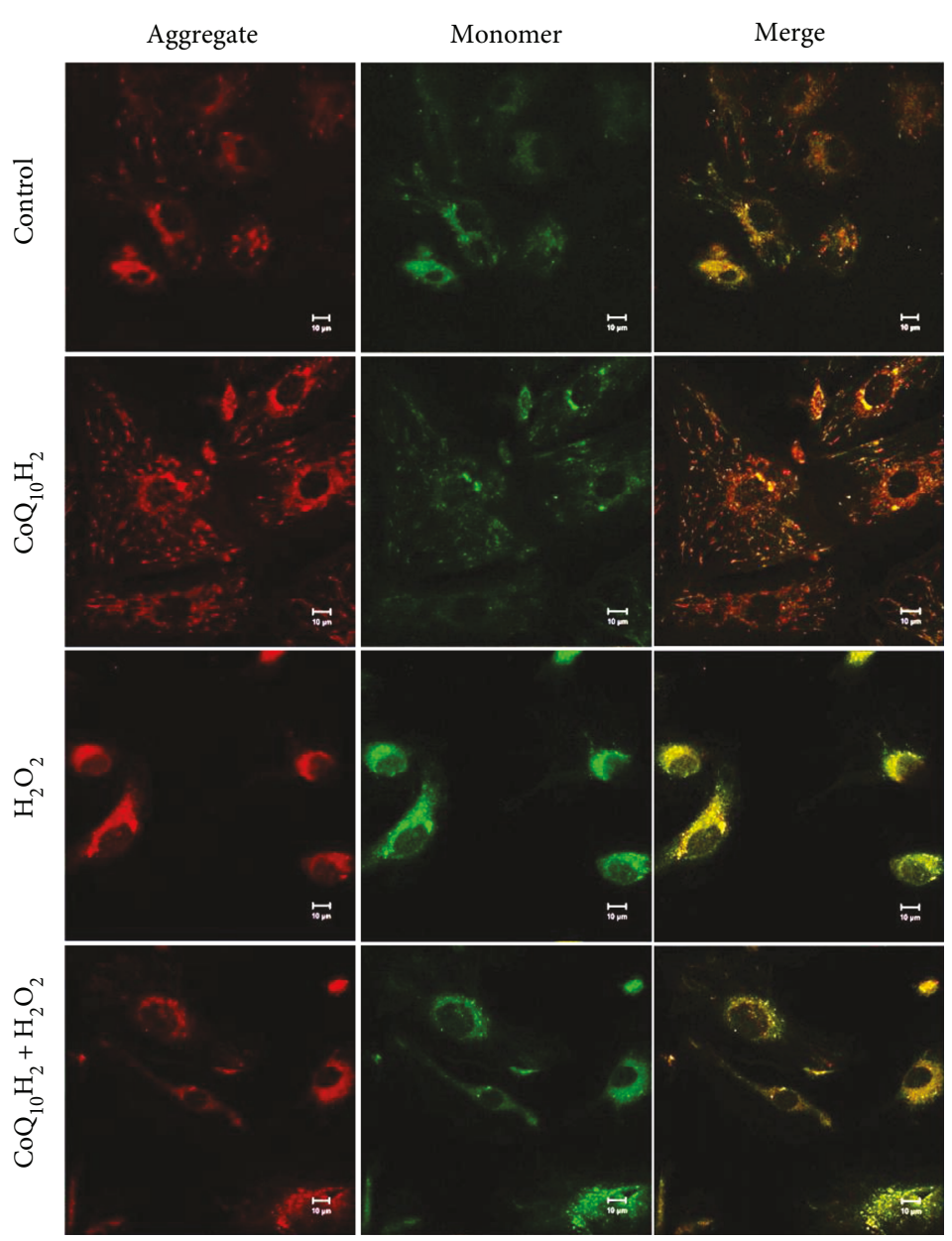

(a)

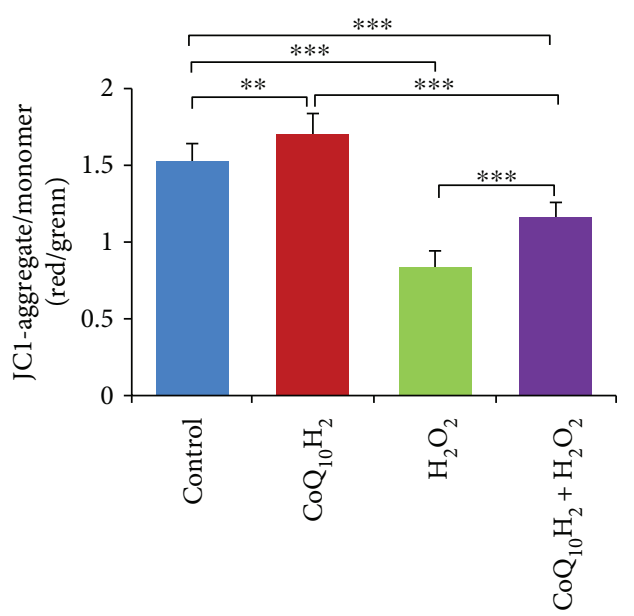

(b)

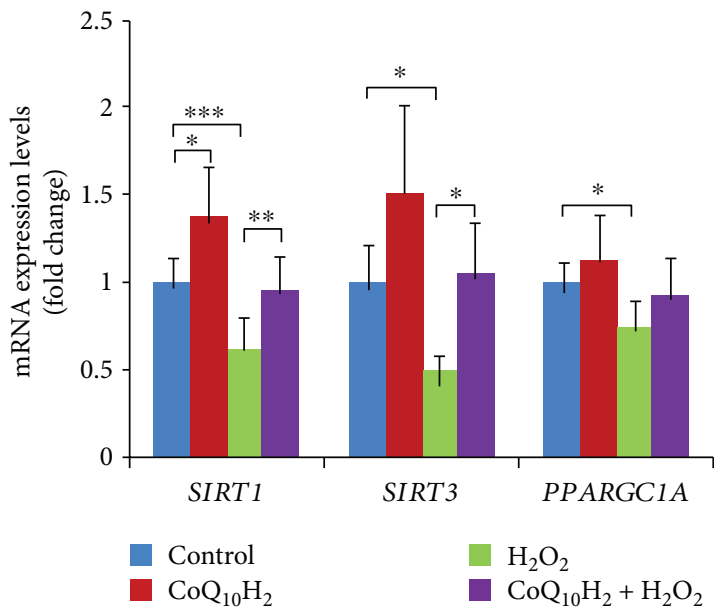

(c)

FIgure 6: Preincubation with $\mathrm{CoQ}_{10} \mathrm{H}_{2}$ prevents $\mathrm{H}_{2} \mathrm{O}_{2}$-induced deterioration of mitochondrial membrane potential in HUVECs. (a) Representative laser scanning microscopy images of aggregated (red) and monomeric (green) JC-1. The two images in each row were captured within the same field and then merged. (b) Mitochondrial depolarization was demonstrated by a change in JC-1 fluorescence from red to green (aggregate/monomer) $(n=6)$. (c) Real-time RT-PCR analysis of SIRT1, SIRT3, and PGC-1 $\alpha$ (PPARGC1A) mRNA expression. Histograms show fold change in mRNA level relative to the control cells $(n=6-9)$. ${ }^{*} P<0.05,{ }^{* *} P<0.01,{ }^{* * *} P<0.001$; oneway ANOVA followed by Tukey's test.

premature senescence caused by oxidative stress. Specifically, we examined the effect of preincubation with $\mathrm{CoQ}_{10} \mathrm{H}_{2}$ prior to $\mathrm{H}_{2} \mathrm{O}_{2}$ exposure on cell senescence, cell proliferation, apoptosis, and oxidative damage as well as how these compounds affected various endothelial cell functions, including eNOS production, mitochondrial activity and migration, and tube formation activities. In addition, we assessed the effect of preincubation with $\mathrm{CoQ}_{10} \mathrm{H}_{2}$ prior to $\mathrm{HG}$ exposure on cell senescence.

In addition to its bioenergetic role as a proton carrier in the mitochondrial respiratory chain, $\mathrm{CoQ}_{10} \mathrm{H}_{2}$ has a protective role by inhibiting lipid peroxidation in membranes and lipoproteins $[19,40]$. Oxidative stress and a proinflammatory state are major characteristics of aging and many age-related disorders, including CVD [41]. During aging of humans and animals, levels of oxidative stress increase, whereas the capacity of antioxidant defense systems and levels of $\mathrm{CoQ}_{10}$ decline $[20,42] . \mathrm{CoQ}_{10}$ supplementation has beneficial effects for both aging subjects and CVD patients by enhancing endothelial function [43]. At a cellular level, the antioxidant effect of $\mathrm{CoQ}_{10}$ on endothelial functions is thought to be mediated through protection against mitochondrial dysfunction [44], although the details of these mitochondria-related mechanisms are unclear, and mitochondria may not be the only cellular site that is affected by CoQ10. Indeed, nonmitochondrial effects of $\mathrm{CoQ}_{10}$ in endothelial cells include regulating NO production and signaling in the Golgi compartment mediated through altered eNOS activity and membrane redox status [24]. eNOS is known to be a critical regulator of cardiovascular functions through its generation of NO, which can slow the progression of endothelial cell senescence and dysfunction $[26,45]$. During aging, NO production by human endothelial cells does decrease [46]. Meanwhile, mRNA expression levels of PAI-1, which is associated with atherosclerosis, and SA- $\beta$-Gal activity, a marker of senescence, were increased in senescent 


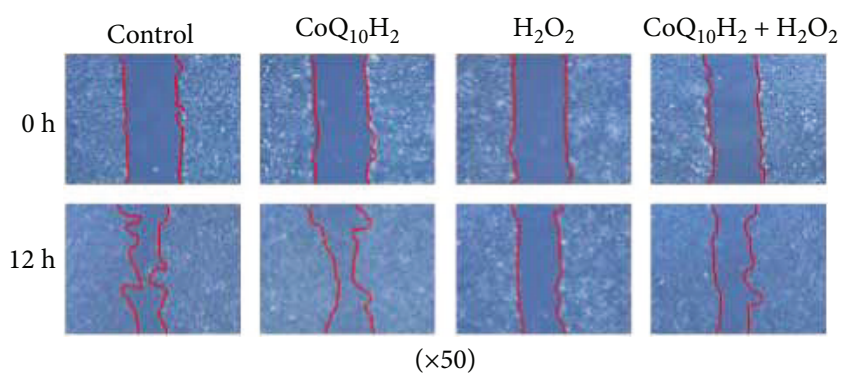

(a)
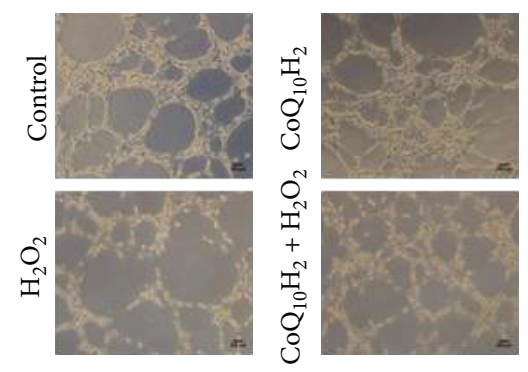

(c)
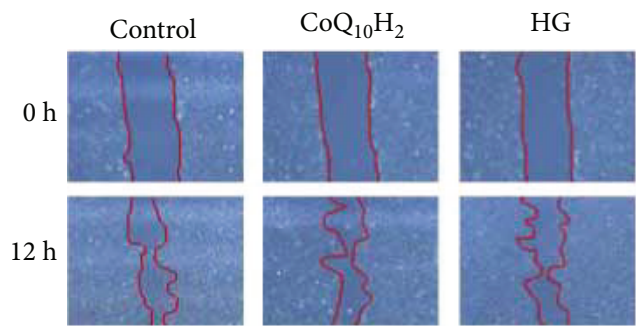

$(\times 50)$

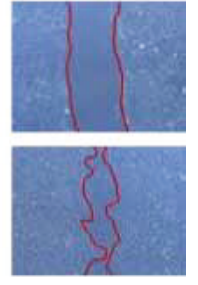

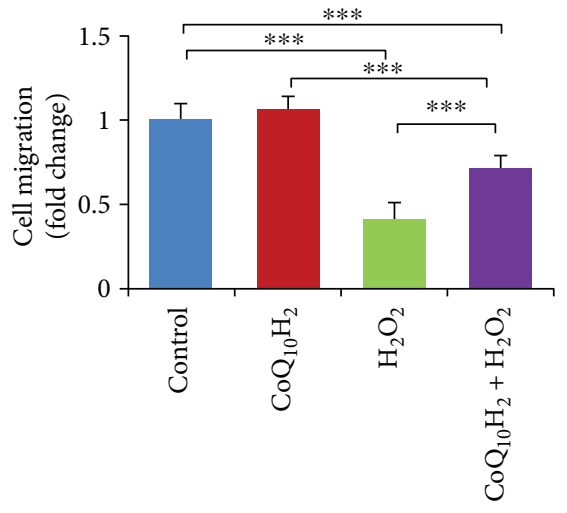

(b)

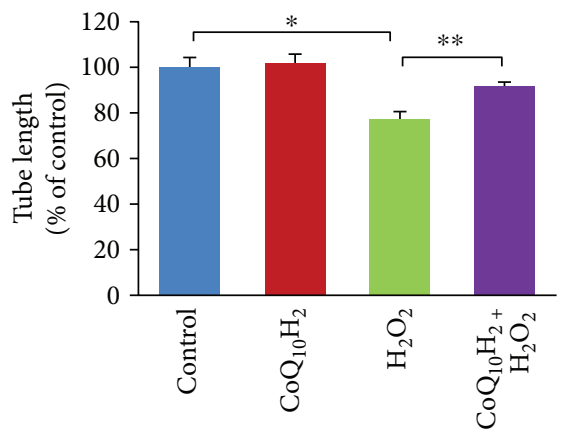

(d) $\mathrm{CoQ}_{10} \mathrm{H}_{2}+\mathrm{HG}$

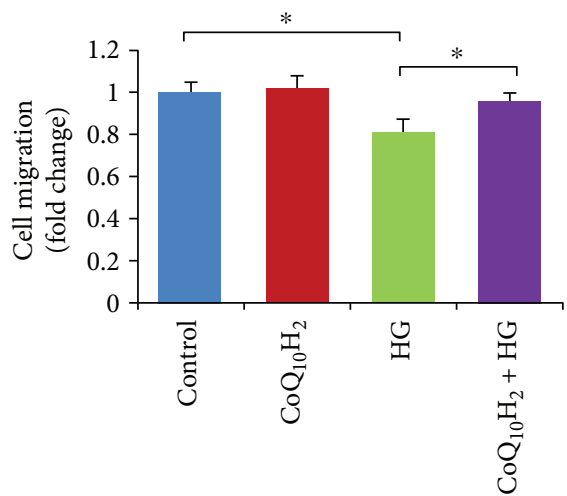

(f)

Figure 7: Preincubation with $\mathrm{CoQ}_{10} \mathrm{H}_{2}$ prevented $\mathrm{H}_{2} \mathrm{O}_{2}$ or HG-induced reduction in migration and tube formation by $\mathrm{HUVEC}$. (a) Representative images of cell migration analysis evaluated using a wound-healing assay conducted over 12 hours in $\mathrm{H}_{2} \mathrm{O}_{2}$-induced reduction of migration. (b) Histograms show fold change in migration activity relative to control cells $(n=9)$. (c) Representative images from a $\mathrm{H}_{2} \mathrm{O}_{2}$-induced tube formation assay after a 6-hour incubation. (d) Histograms show fold change in total cell tube length relative to control cells $(n=6)$. (e) Representative images of cell migration over 12 hours evaluated using a wound-healing assay in HG-induced reduction of migration. (f) Histogram shows fold change in migration activity relative to control cells $(n=3) .{ }^{*} P<0.05$, ${ }^{* *} P<0.01$, and ${ }^{* * *} P<0.001$; mean $\pm \mathrm{SD}$, one-way ANOVA followed by Tukey's test.

endothelial cells and aortas from aged mice, respectively [47]. $\mathrm{H}_{2} \mathrm{O}_{2}$ can induce premature senescence and apoptosis in endothelial cells [48, 49], and $\mathrm{H}_{2} \mathrm{O}_{2}$ acts as an oxidative stressor to modulate levels of endogenous oxidants and ROS products $[50,51]$.
Our previous studies revealed that dietary supplementation with the reduced form of $\mathrm{CoQ}_{10} \mathrm{H}_{2}$ could effectively improve mitochondrial functions, inhibit oxidative stress in the liver, and decelerate senescence in senescenceaccelerated mice (SAMP1 strain) [27]. Subsequently, we also 


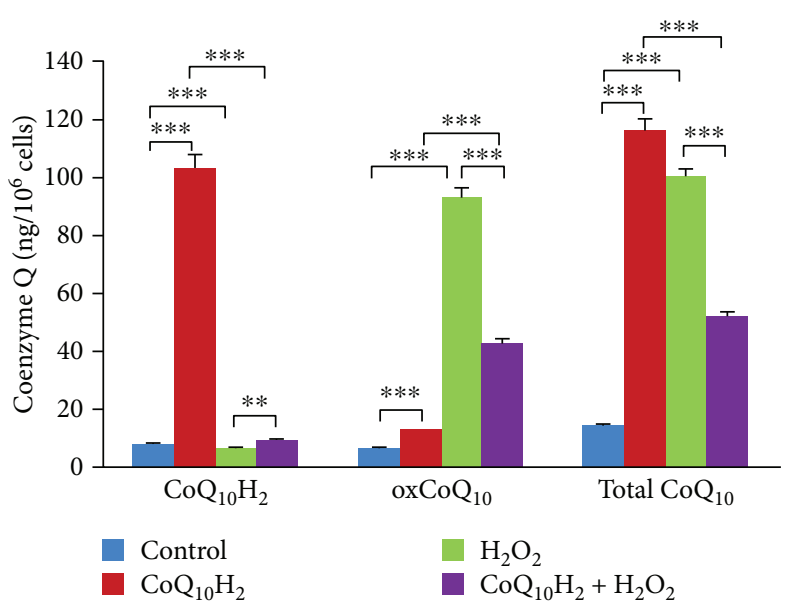

(a)

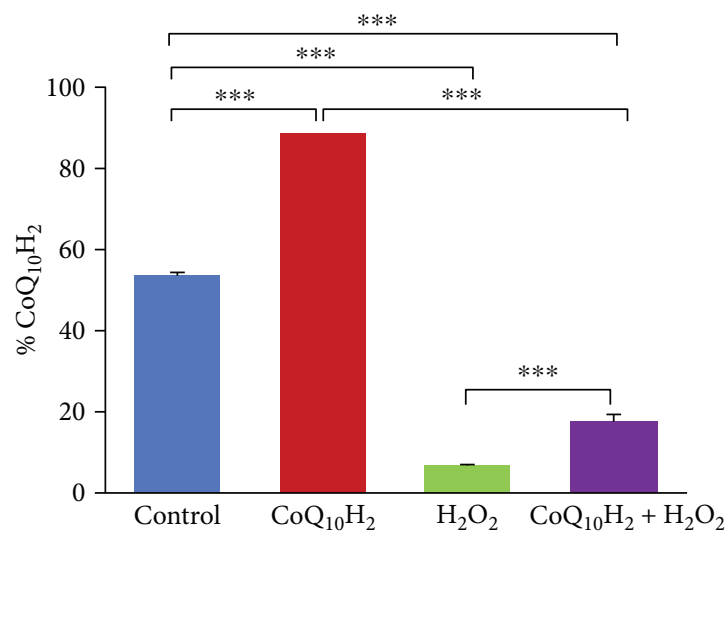

(b)

Figure 8: Intracellular $\mathrm{CoQ}_{10} \mathrm{H}_{2}$ and oxCoQ ${ }_{10}$ levels in HUVECs changed dramatically after treatment with $\mathrm{H}_{2} \mathrm{O}_{2}$ and $\mathrm{CoQ}_{10} \mathrm{H}_{2}$. (a) The amount of reduced $\left(\mathrm{CoQ}_{10} \mathrm{H}_{2}\right)$ and oxidized $($ oxCoQ 10$)$ forms of coenzyme Q10 in whole cell extracts was determined. (b) The percentage of $\mathrm{CoQ}_{10} \mathrm{H}_{2}$ in total coenzyme Q10 (Total $\left.\mathrm{CoQ}_{10}\right)$ was calculated $(n=4) .{ }^{* *} P<0.01,{ }^{* * *} P<0.001$; one-way ANOVA followed by Tukey's test.

found that dietary supplementation with $\mathrm{CoQ}_{10} \mathrm{H}_{2}$ of $\mathrm{KKAy}$ mice reduced the amount of white adipose tissue and enhanced the function of brown adipose tissue by promoting lipid metabolism [30]. In these studies, we showed that $\mathrm{CoQ}_{10} \mathrm{H}_{2}$ decreases cytoplasmic $\mathrm{Ca}^{2+}$ in liver cells by enhancing activity of $\mathrm{Ca}^{2+}$ pumps in the endoplasmic reticulum, which in turn led to increased cAMP levels and enhanced activity of mitochondrial antioxidant defense systems via upregulated gene expression of $A M P K$, SIRT1, and PGC1- $\alpha$ signaling proteins [30]. Here, we determined the optimal concentration and times for preincubation with $\mathrm{CoQ}_{10} \mathrm{H}_{2}$ and incubation with $\mathrm{H}_{2} \mathrm{O}_{2}$ in HUVECs using SIRT1 expression and cell viability, respectively, as indices.

The SASP includes expression of proinflammatory cytokines, tumor necrosis factors, and matrix metalloproteinases in body tissues and is a hallmark of biological and premature aging [52]. Cellular senescence progression is thought to be regulated by the tumor suppressor pathways p14ARF/p53/ p21 and p16INK4a/retinoblastoma (Rb) $[53,54]$. Treatment with $\mathrm{H}_{2} \mathrm{O}_{2}$ negatively impacts cellular functions as well induces senescence and apoptosis in various cells, including endothelial cells $[48,55]$. CoQ10 has been reported to decrease expression of proinflammatory cytokines in replicative senescent HUVECs and p53, p21, and p16 ${ }^{\mathrm{INK} 4 \mathrm{a}}$ expression in induced premature mesenchymal stem cells $[31,56]$. Our results showed that preincubation of HUVECs with $\mathrm{CoQ}_{10} \mathrm{H}_{2}$ protected against senescence, apoptosis, and necrosis induced by $\mathrm{H}_{2} \mathrm{O}_{2}$ and also promoted rescue from ROS overproduction, mitochondria hypofunction, and diminished NO production. Furthermore, $\mathrm{CoQ}_{10} \mathrm{H}_{2}$-mediated inhibition of increased intracellular $\mathrm{Ca}^{2+}$ levels after $\mathrm{H}_{2} \mathrm{O}_{2}$ treatment (Figure S3) is consistent with our previous results obtained with hepatocarcinoma HepG2 cells [30].

Using the fluorescent dye JC-1 [57] to analyze functional damage of mitochondria by assessing changes in mitochondrial membrane potential (MMP), we found that pretreatment with $\mathrm{CoQ}_{10} \mathrm{H}_{2}$ could mitigate $\mathrm{H}_{2} \mathrm{O}_{2}$-induced reductions in MMP, which must be preserved to avoid apoptosis [58]. SIRT1 is proposed to be a critical gene in aging and age-related diseases [59] that affects mitochondrial biogenesis through regulation of $P G C-1 \alpha$ expression [60], whereas mitochondrial SIRT3 activates mitochondrial antioxidant defense systems in the presence of caloric restriction (CR) [61]. Consistent with these earlier findings, here, we showed that $\mathrm{CoQ}_{10} \mathrm{H}_{2}$ enhanced activity of the mitochondrial antioxidative system in HUVECs.

Angiogenesis is the physiological process wherein new capillaries grow from existing vessels. Endothelial cell functions such as migration and tube formation play important roles in the formation of these vessel sprouts [62, 63]. Our results suggested that $\mathrm{CoQ}_{10} \mathrm{H}_{2}$ can enhance activity of microvascular endothelial cells to promote wound repair while also impairing formation of tube-like structure induced by oxidative stress.

$\mathrm{CoQ}_{10}$ is endogenously produced in all cells, and its reduced form $\left(\mathrm{CoQ}_{10} \mathrm{H}_{2}\right)$ has important antioxidative effects $[19,40]$. In this study, we detected dramatic increases in cellular $\mathrm{CoQ}_{10} \mathrm{H}_{2}$ concentrations following supplementation with $\mathrm{CoQ}_{10} \mathrm{H}_{2}$ in media for HUVEC culture, which is similar to previous findings [64]. Exposure of HUVECs to $\mathrm{H}_{2} \mathrm{O}_{2}$ resulted in a rapid increase in cellular oxCoQ ${ }_{10}$ (Figure 8, Figure S6A), and this effect was prevented in part by pretreatment with $\mathrm{CoQ}_{10} \mathrm{H}_{2}$ (Figure 8). We analyzed the mRNA expression of PDSS2 and COQ2 and the important enzymes for $\mathrm{CoQ}_{10}$ biosynthesis and found that the expression levels for both increased significantly (Figure S6C). Additional studies will be needed to fully characterize the effect of $\mathrm{H}_{2} \mathrm{O}_{2}$ on $\mathrm{CoQ}_{10}$ biosynthesis, which is known to involve at least 13 genes (e.g., PDSS2, COQ1, COQ2, and COQ3) [65]. Increased amounts of total $\mathrm{CoQ}_{10}$ induced by $\mathrm{H}_{2} \mathrm{O}_{2}$ treatment could indicate that oxidative damage promotes increased biosynthesis of oxCoQ ${ }_{10}$ and that $\mathrm{CoQ}_{10} \mathrm{H}_{2}$ supplementation curbs the effect 
of $\mathrm{H}_{2} \mathrm{O}_{2}$. The limited cellular incorporation of $\mathrm{CoQ}_{10}$ in the surviving cell population in the presence of oxidative stress induced by $\mathrm{H}_{2} \mathrm{O}_{2}$ treatment suggests that surviving cells may invoke an adaptive response mediated through upregulation of $\mathrm{CoQ}_{10}$ synthesis. However, increased amounts of oxCoQ $\mathrm{Q}_{10}$ might not translate to enhanced viability and functionality in light of the very high percentage of ${ }^{\circ} \mathrm{CoQ}_{10}$ that could disrupt the optimal reduced state of $\mathrm{CoQ}_{10}$ in $\mathrm{H}_{2} \mathrm{O}_{2}$-exposed cells. Taken together, our results indicate that $\mathrm{CoQ}_{10} \mathrm{H}_{2}$ plays a critical role in cellular processes and $\mathrm{CoQ}_{10}$ synthesis, but further studies are needed to elucidate the mechanism and biological significance of the observed $\mathrm{CoQ}_{10}$ upregulation.

Finally, we selected the concentration of $\mathrm{H}_{2} \mathrm{O}_{2}(100 \mu \mathrm{M})$ based on previous reports $[48,49]$. We showed that $100 \mu \mathrm{M}$ $\mathrm{H}_{2} \mathrm{O}_{2}$ affected eNOS and PAI-1 mRNA expression in HUVECs and reduced cell viability to $20 \%$ (Figures S1E and F). To determine cell viability, we used the MTT method, which can provide information not only for cytotoxicity and cell proliferation but also for mitochondrial activation [66-68]. Thus, it is clear that the mechanism by which $\mathrm{CoQ}_{10} \mathrm{H}_{2}$ preincubation protects against the negative effects of $\mathrm{H}_{2} \mathrm{O}_{2}$ treatment is complex, and for a selected population of HUVECs, cellular senescence and mitochondrial function may also be involved. Additional investigations will be needed to characterize the detailed effects of $\mathrm{CoQ}_{10} \mathrm{H}_{2}$ on dysfunction induced by oxidative stress in endothelial cells.

In conclusion, $\mathrm{H}_{2} \mathrm{O}_{2}$ can induce HUVEC senescence through oxidative stress and increased ROS production. $\mathrm{CoQ}_{10} \mathrm{H}_{2}$ can markedly increase resistance to oxidative damage by enhancing mitochondrial function as well as prevent senescence and diminished function of endothelial cells treated with $\mathrm{H}_{2} \mathrm{O}_{2}$. Our results would facilitate another perspective for the investigation of the potential of $\mathrm{CoQ}_{10} \mathrm{H}_{2}$ to protect against age-associated exacerbation of CVD. In vivo studies will be needed to study how $\mathrm{CoQ}_{10} \mathrm{H}_{2}$ affects the development of endothelial dysfunction and the mechanisms by which $\mathrm{CoQ}_{10} \mathrm{H}_{2}$ regulates endothelial cell aging in both older individuals and CVD patients.

\section{Conflicts of Interest}

The authors declare that they have no competing interests.

\section{Authors' Contributions}

Jia Huo, Masayuki Mori, Jinko Sawashita, and Keiichi Higuchi conceived and designed the experiments. Jia Huo, Zhe Xu, Hiroki Miyahara, and Jian Dai performed the experiments. Jia Huo, Zhe Xu, Hiroki Miyahara, Kazunori Hosoe, and Jinko Sawashita analyzed the data. Kazunori Hosoe and Hiroshi Kubo contributed reagents and materials. Jia Huo and Keiichi Higuchi wrote the paper.

\section{Acknowledgments}

The authors thank the Kaneka Corporation of Japan for providing the $\mathrm{CoQ}_{10} \mathrm{H}_{2}$ and ${ }^{\circ} \mathrm{CoQ}_{10}$. The authors thank $\mathrm{Mr}$. Kiyokazu Kametani and Ms. Kayo Suzuki (Research Center for Support to Advanced Science, Shinshu University) for their skillful technical assistance. This work is supported in part by a grant-in-aid for Scientific Research from Kobayashi International Scholarship Foundation, Japan.

\section{Supplementary Materials}

Table S1: primer sequences for real-time RT-PCR. Figure S1: $\mathrm{H}_{2} \mathrm{O}_{2}, \mathrm{CoQ}_{10} \mathrm{H}_{2}$, and oxCoQ $\mathrm{C}_{10}$ affect HUVEC-related gene expression and $\mathrm{CoQ}_{10} \mathrm{H}_{2}$ prevents $\mathrm{H}_{2} \mathrm{O}_{2}$-mediated decreases in cell viability. Figure S2: preincubation with $\mathrm{CoQ}_{10} \mathrm{H}_{2}$ prevented $\mathrm{H}_{2} \mathrm{O}_{2}$-induced reduction of cell proliferation in HUVECs. Figure S3: $\mathrm{CoQ}_{10} \mathrm{H}_{2}$ blocks $\mathrm{H}_{2} \mathrm{O}_{2}$-induced increases in free cytosolic $\mathrm{Ca}^{2+}$ levels in endothelial cells. Figure S4: $\mathrm{CoQ}_{10} \mathrm{H}_{2}$ treatment prevented $\mathrm{H}_{2} \mathrm{O}_{2}$-induced reduction in migration and tube formation. Figure S5: $\mathrm{CoQ}_{10} \mathrm{H}_{2}$ affects $\mathrm{H}_{2} \mathrm{O}_{2}$-dependent reduction in endothelial cell migration. Figure S6: $\mathrm{CoQ}_{10} \mathrm{H}_{2}$ and ${ }^{x} \mathrm{CoQ}_{10}$ levels in HUVECs increased after $\mathrm{H}_{2} \mathrm{O}_{2}$ treatment. (Supplementary Materials)

\section{References}

[1] B. Xue, J. Head, and A. McMunn, "The associations between retirement and cardiovascular disease risk factors in China: a 20-year prospective study," American Journal of Epidemiology, vol. 185, no. 8, pp. 688-696, 2017.

[2] J. A. Finegold, P. Asaria, and D. P. Francis, "Mortality from ischaemic heart disease by country, region, and age: statistics from World Health Organisation and United Nations," International Journal of Cardiology, vol. 168, no. 2, pp. 934-945, 2013.

[3] E. G. Lakatta and D. Levy, "Arterial and cardiac aging: major shareholders in cardiovascular disease enterprises: part I: aging arteries: a "set up" for vascular disease," Circulation, vol. 107, no. 1, pp. 139-146, 2003.

[4] D. D. Haines, B. Juhasz, and A. Tosaki, "Management of multicellular senescence and oxidative stress," Journal of Cellular and Molecular Medicine, vol. 17, no. 8, pp. 936-957, 2013.

[5] G. L. Pierce, L. A. Lesniewski, B. R. Lawson, S. D. Beske, and D. R. Seals, "Nuclear factor $-\kappa \mathrm{B}$ activation contributes to vascular endothelial dysfunction via oxidative stress in overweight/ obese middle-aged and older humans," Circulation, vol. 119, no. 9, pp. 1284-1292, 2009.

[6] J. C. Acosta, A. O'Loghlen, A. Banito et al., "Chemokine signaling via the CXCR2 receptor reinforces senescence," Cell, vol. 133, no. 6, pp. 1006-1018, 2008.

[7] L. Hayflick and P. S. Moorhead, "The serial cultivation of human diploid cell strains," Experimental Cell Research, vol. 25, no. 3, pp. 585-621, 1961.

[8] W. Zhang, R. Hui, and S. Yang, "Telomeres, cardiovascular aging, and potential intervention for cellular senescence," Science China. Life Sciences, vol. 57, no. 8, pp. 858-862, 2014.

[9] P. Davalli, T. Mitic, A. Caporali, A. Lauriola, and D. D'Arca, "ROS, cell senescence, and novel molecular mechanisms in aging and age-related diseases," Oxidative Medicine and Cellular Longevity, vol. 2016, Article ID 3565127, 18 pages, 2016.

[10] A. Dimozi, E. Mavrogonatou, A. Sklirou, and D. Kletsas, "Oxidative stress inhibits the proliferation, induces premature senescence and promotes a catabolic phenotype in human 
nucleus pulposus intervertebral disc cells," European Cells \& Materials, vol. 30, pp. 89-103, 2015.

[11] F. Zanichelli, S. Capasso, G. Di Bernardo et al., "Low concentrations of isothiocyanates protect mesenchymal stem cells from oxidative injuries, while high concentrations exacerbate DNA damage," Apoptosis, vol. 17, no. 9, pp. 964-974, 2012.

[12] H. Oeseburg, R. A. de Boer, H. Buikema, P. van der Harst, W. H. van Gilst, and H. H. W. Sillje, "Glucagon-like peptide 1 prevents reactive oxygen species-induced endothelial cell senescence through the activation of protein kinase A," Arteriosclerosis, Thrombosis, and Vascular Biology, vol. 30, no. 7, pp. 1407-1414, 2010.

[13] O. Toussaint, E. E. Medrano, and T. von Zglinicki, "Cellular and molecular mechanisms of stress-induced premature senescence (SIPS) of human diploid fibroblasts and melanocytes," Experimental Gerontology, vol. 35, no. 8, pp. 927-945, 2000.

[14] T. Michel and P. M. Vanhoutte, "Cellular signaling and NO production,” Pflügers Archiv, vol. 459, no. 6, pp. 807-816, 2010.

[15] C. Regina, E. Panatta, E. Candi et al., "Vascular ageing and endothelial cell senescence: molecular mechanisms of physiology and diseases," Mechanisms of Ageing and Development, vol. 159, pp. 14-21, 2016.

[16] D. R. Seals, K. L. Jablonski, and A. J. Donato, "Aging and vascular endothelial function in humans," Clinical Science (London, England), vol. 120, no. 9, pp. 357-375, 2011.

[17] H. J. Park, Y. Zhang, S. P. Georgescu, K. L. Johnson, D. Kong, and J. B. Galper, "Human umbilical vein endothelial cells and human dermal microvascular endothelial cells offer new insights into the relationship between lipid metabolism and angiogenesis," Stem Cell Reviews, vol. 2, no. 2, pp. 93-101, 2006.

[18] W. C. Lee and T. H. Tsai, "Preparation and characterization of liposomal coenzyme Q10 for in vivo topical application," International Journal of Pharmaceutics, vol. 395, no. 1-2, pp. 78-83, 2010.

[19] M. Bentinger, M. Tekle, and G. Dallner, "Coenzyme Q - biosynthesis and functions," Biochemical and Biophysical Research Communications, vol. 396, no. 1, pp. 74-79, 2010.

[20] F. Aberg, E. L. Appelkvist, G. Dallner, and L. Ernster, "Distribution and redox state of ubiquinones in rat and human tissues," Archives of Biochemistry and Biophysics, vol. 295, no. 2, pp. 230-234, 1992.

[21] J. Naderi, M. Somayajulu-Nitu, A. Mukerji et al., "Water-soluble formulation of coenzyme Q10 inhibits Bax-induced destabilization of mitochondria in mammalian cells," Apoptosis, vol. 11, no. 8, pp. 1359-1369, 2006.

[22] K. Toyama, S. Sugiyama, H. Oka et al., "Rosuvastatin combined with regular exercise preserves coenzyme Q10 levels associated with a significant increase in high-density lipoprotein cholesterol in patients with coronary artery disease," Atherosclerosis, vol. 217, no. 1, pp. 158-164, 2011.

[23] A. Kontush, C. Hubner, B. Finckh, A. Kohlschutter, and U. Beisiegel, "Antioxidative activity of ubiquinol-10 at physiologic concentrations in human low density lipoprotein," Biochimica et Biophysica Acta, vol. 1258, no. 2, pp. 177187, 1995.

[24] V. Mugoni, R. Postel, V. Catanzaro et al., "Ubiad1 is an antioxidant enzyme that regulates eNOS activity by CoQ10 synthesis," Cell, vol. 152, no. 3, pp. 504-518, 2013.
[25] L. Wang, P. Zhang, Y. Wei, Y. Gao, R. Patient, and F. Liu, "A blood flow-dependent klf2a-NO signaling cascade is required for stabilization of hematopoietic stem cell programming in zebrafish embryos," Blood, vol. 118, no. 15, pp. 41024110, 2011.

[26] H. Ota, M. Eto, S. Ogawa, K. Iijima, M. Akishita, and Y. Ouchi, "SIRT1/eNOS axis as a potential target against vascular senescence, dysfunction and atherosclerosis," Journal of Atherosclerosis and Thrombosis, vol. 17, no. 5, pp. 431-435, 2010.

[27] G. Tian, J. Sawashita, H. Kubo et al., "Ubiquinol-10 supplementation activates mitochondria functions to decelerate senescence in senescence-accelerated mice," Antioxidants \& Redox Signaling, vol. 20, no. 16, pp. 2606-2620, 2014.

[28] M. J. Zarzuelo, R. Lopez-Sepulveda, M. Sanchez et al., "SIRT1 inhibits NADPH oxidase activation and protects endothelial function in the rat aorta: implications for vascular aging," Biochemical Pharmacology, vol. 85, no. 9, pp. 1288 1296, 2013.

[29] G. Arunachalam, H. Yao, I. K. Sundar, S. Caito, and I. Rahman, "SIRT1 regulates oxidant- and cigarette smoke-induced eNOS acetylation in endothelial cells: role of resveratrol," Biochemical and Biophysical Research Communications, vol. 393, no. 1, pp. 66-72, 2010.

[30] Z. Xu, J. Huo, X. Ding et al., "Coenzyme Q10 improves lipid metabolism and ameliorates obesity by regulating CaMKIImediated PDE4 inhibition," Scientific Reports, vol. 7, no. 1, p. $8253,2017$.

[31] F. Olivieri, R. Lazzarini, L. Babini et al., "Anti-inflammatory effect of ubiquinol-10 on young and senescent endothelial cells via miR-146a modulation," Free Radical Biology \& Medicine, vol. 63, pp. 410-420, 2013.

[32] Y. Pan, Q. Wu, L. Qin, J. Cai, and B. du, "Gold nanoparticles inhibit $\mathrm{VEGF}_{165}$-induced migration and tube formation of endothelial cells via the Akt pathway," BioMed Research International, vol. 2014, Article ID 418624, 11 pages, 2014.

[33] L. Zhang, M. Zhou, G. Qin, N. L. Weintraub, and Y. Tang, "MiR-92a regulates viability and angiogenesis of endothelial cells under oxidative stress," Biochemical and Biophysical Research Communications, vol. 446, no. 4, pp. 952-958, 2014.

[34] L. Scorrano, S. A. Oakes, J. T. Opferman et al., "BAX and BAK regulation of endoplasmic reticulum $\mathrm{Ca}^{2+}$ : a control point for apoptosis," Science, vol. 300, no. 5616, pp. 135-139, 2003.

[35] J. Ruiz-Jimenez, F. Priego-Capote, J. M. Mata-Granados, J. M. Quesada, and M. D. Luque de Castro, "Determination of the ubiquinol-10 and ubiquinone-10 (coenzyme Q10) in human serum by liquid chromatography tandem mass spectrometry to evaluate the oxidative stress," Journal of Chromatography A, vol. 1175, no. 2, pp. 242-248, 2007.

[36] W. L. Lu, Q. Zhang, H. S. Lee et al., "Total coenzyme Q10 concentrations in Asian men following multiple oral 50-mg doses administered as coenzyme Q10 sustained release tablets or regular tablets," Biological \& Pharmaceutical Bulletin, vol. 26, no. 1, pp. 52-55, 2003.

[37] T. Hayashi, H. Matsui-Hirai, A. Miyazaki-Akita et al., "Endothelial cellular senescence is inhibited by nitric oxide: implications in atherosclerosis associated with menopause and diabetes," Proceedings of the National Academy of Sciences of the United States of America, vol. 103, no. 45, pp. 1701817023, 2006.

[38] T. Zhang, F. Tian, J. Wang et al., "Donepezil attenuates high glucose-accelerated senescence in human umbilical vein 
endothelial cells through SIRT1 activation," Cell Stress \& Chaperones, vol. 20, no. 5, pp. 787-792, 2015.

[39] L. Sun, H. Y. Yau, W. Y. Wong, R. A. Li, Y. Huang, and X. Yao, "Role of TRPM2 in $\mathrm{H}_{2} \mathrm{O}_{2}$-induced cell apoptosis in endothelial cells," PLoS One, vol. 7, no. 8, article e43186, 2012.

[40] F. L. Crane, "The evolution of coenzyme Q," BioFactors, vol. 32, no. 1-4, pp. 5-11, 2008.

[41] T. J. Guzik and R. M. Touyz, "Oxidative stress, inflammation, and vascular aging in hypertension," Hypertension, vol. 70, no. 4, pp. 660-667, 2017.

[42] E. Doria, D. Buonocore, A. Focarelli, and F. Marzatico, "Relationship between human aging muscle and oxidative system pathway," Oxidative Medicine and Cellular Longevity, vol. 2012, Article ID 830257, 13 pages, 2012.

[43] Y. L. Dai, T. H. Luk, K. H. Yiu et al., "Reversal of mitochondrial dysfunction by coenzyme Q10 supplement improves endothelial function in patients with ischaemic left ventricular systolic dysfunction: a randomized controlled trial," Atherosclerosis, vol. 216, no. 2, pp. 395-401, 2011.

[44] M. Durán-Prado, J. Frontiñán, R. Santiago-Mora et al., "Coenzyme $\mathrm{Q}_{10}$ protects human endothelial cells from $\beta$-amyloid uptake and oxidative stress-induced injury," PLoS One, vol. 9, no. 10, article e109223, 2014.

[45] U. Forstermann and W. C. Sessa, "Nitric oxide synthases: regulation and function," European Heart Journal, vol. 33, no. 7, pp. 829-837, 2012.

[46] C. Rippe, M. Blimline, K. A. Magerko et al., "MicroRNA changes in human arterial endothelial cells with senescence: relation to apoptosis, eNOS and inflammation," Experimental Gerontology, vol. 47, no. 1, pp. 45-51, 2012.

[47] Y. Z. Wan, P. Gao, S. Zhou et al., "SIRT1-mediated epigenetic downregulation of plasminogen activator inhibitor-1 prevents vascular endothelial replicative senescence," Aging Cell, vol. 13, no. 5, pp. 890-899, 2014.

[48] Z. Song, Y. Liu, B. Hao et al., "Ginsenoside Rb1 prevents $\mathrm{H}_{2} \mathrm{O}_{2}$-induced HUVEC senescence by stimulating sirtuin-1 pathway," PLoS One, vol. 9, no. 11, article e112699, 2014.

[49] Y. Sun, X. Hu, G. Hu, C. Xu, and H. Jiang, "Curcumin attenuates hydrogen peroxide-induced premature senescence via the activation of SIRT1 in human umbilical vein endothelial cells," Biological \& Pharmaceutical Bulletin, vol. 38, no. 8, pp. 11341141, 2015.

[50] Y. Ido, A. Duranton, F. Lan et al., "Acute activation of AMPactivated protein kinase prevents $\mathrm{H}_{2} \mathrm{O}_{2}$-induced premature senescence in primary human keratinocytes," PLoS One, vol. 7, no. 4, article e35092, 2012.

[51] H. Oeseburg, D. Iusuf, P. van der Harst, W. H. van Gilst, R. H. Henning, and A. J. M. Roks, "Bradykinin protects against oxidative stress-induced endothelial cell senescence," Hypertension, vol. 53, no. 2, pp. 417-422, 2009.

[52] A. Freund, A. V. Orjalo, P. Y. Desprez, and J. Campisi, "Inflammatory networks during cellular senescence: causes and consequences," Trends in Molecular Medicine, vol. 16, no. 5, pp. 238-246, 2010.

[53] B. Jie, C. Weilong, C. Ming et al., "Enhancer of zeste homolog 2 depletion induces cellular senescence via histone demethylation along the INK4/ARF locus," The International Journal of Biochemistry \& Cell Biology, vol. 65, pp. 104-112, 2015.

[54] T. D. Halazonetis, V. G. Gorgoulis, and J. Bartek, "An oncogene-induced DNA damage model for cancer development," Science, vol. 319, no. 5868, pp. 1352-1355, 2008.
[55] K. Irani, "Oxidant signaling in vascular cell growth, death, and survival: a review of the roles of reactive oxygen species in smooth muscle and endothelial cell mitogenic and apoptotic signaling," Circulation Research, vol. 87, no. 3, pp. 179-183, 2000.

[56] D. Zhang, B. Yan, S. Yu et al., "Coenzyme Q10 inhibits the aging of mesenchymal stem cells induced by D-galactose through Akt/mTOR signaling," Oxidative Medicine and Cellular Longevity, vol. 2015, Article ID 867293, 10 pages, 2015.

[57] W. J. Shangguan, H. Li, and Y. H. Zhang, "Induction of G2/M phase cell cycle arrest and apoptosis by ginsenoside Rf in human osteosarcoma MG-63 cells through the mitochondrial pathway," Oncology Reports, vol. 31, no. 1, pp. 305-313, 2014.

[58] J. D. Ly, D. R. Grubb, and A. Lawen, "The mitochondrial membrane potential $\left(\Delta \psi_{\mathrm{m}}\right)$ in apoptosis; an update," Apoptosis, vol. 8, no. 2, pp. 115-128, 2003.

[59] W. Cai, M. Ramdas, L. Zhu, X. Chen, G. E. Striker, and H. Vlassara, "Oral advanced glycation endproducts (AGEs) promote insulin resistance and diabetes by depleting the antioxidant defenses AGE receptor-1 and sirtuin 1," Proceedings of the National Academy of Sciences of the United States of America, vol. 109, no. 39, pp. 15888-15893, 2012.

[60] K. J. Menzies and D. A. Hood, "The role of SirT1 in muscle mitochondrial turnover," Mitochondrion, vol. 12, no. 1, pp. 5-13, 2012.

[61] S. Someya, W. Yu, W. C. Hallows et al., "Sirt3 mediates reduction of oxidative damage and prevention of age-related hearing loss under caloric restriction," Cell, vol. 143 , no. 5, pp. $802-$ $812,2010$.

[62] J. Folkman and Y. Shing, "Angiogenesis," The Journal of Biological Chemistry, vol. 267, no. 16, pp. 10931-10934, 1992.

[63] P. F. T. Cezar-de-Mello, V. Nascimento-Silva, C. G. Villela, and I. M. Fierro, "Aspirin-triggered lipoxin A4 inhibition of VEGF-induced endothelial cell migration involves actin polymerization and focal adhesion assembly," Oncogene, vol. 25, no. 1, pp. 122-129, 2006.

[64] S. R. Thomas, S. B. Leichtweis, K. Pettersson et al., "Dietary cosupplementation with vitamin $\mathrm{E}$ and coenzyme $\mathrm{Q}_{10}$ inhibits atherosclerosis in apolipoprotein E gene knockout mice," Arteriosclerosis, Thrombosis, and Vascular Biology, vol. 21, no. 4, pp. 585-593, 2001.

[65] M. Doimo, M. A. Desbats, C. Cerqua, M. Cassina, E. Trevisson, and L. Salviati, "Genetics of coenzyme q10 deficiency," Molecular Syndromology, vol. 5, no. 3-4, pp. 156-162, 2014.

[66] D. Gerlier and N. Thomasset, "Use of MTT colorimetric assay to measure cell activation," Journal of Immunological Methods, vol. 94, no. 1-2, pp. 57-63, 1986.

[67] T. Mosmann, "Rapid colorimetric assay for cellular growth and survival: application to proliferation and cytotoxicity assays," Journal of Immunological Methods, vol. 65, no. 1-2, pp. 55-63, 1983.

[68] F. Denizot and R. Lang, "Rapid colorimetric assay for cell growth and survival: modifications to the tetrazolium dye procedure giving improved sensitivity and reliability," Journal of Immunological Methods, vol. 89, no. 2, pp. 271-277, 1986. 


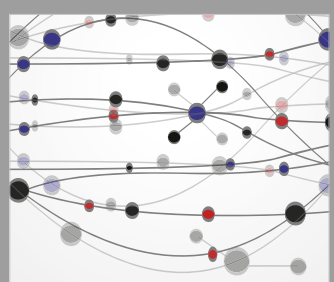

The Scientific World Journal
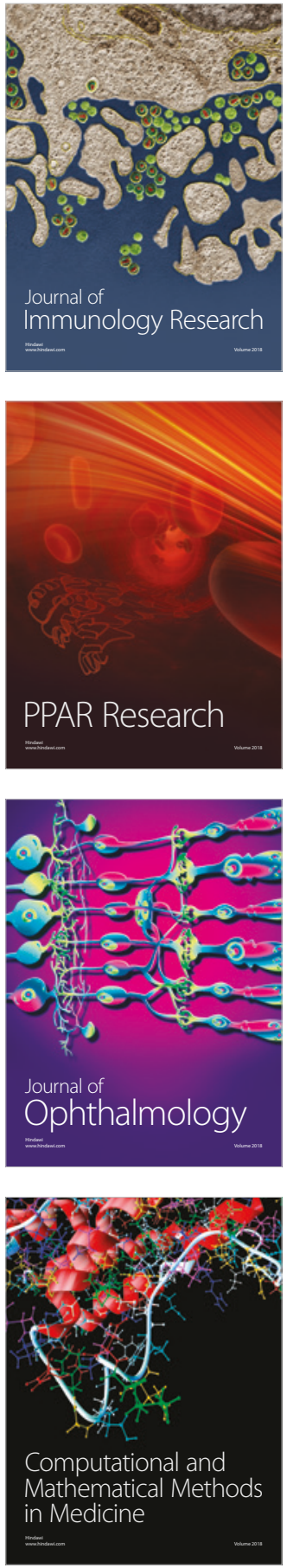

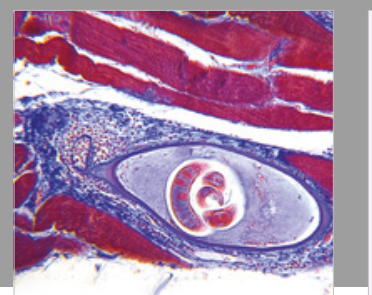

Gastroenterology Research and Practice

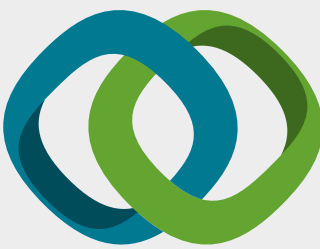

\section{Hindawi}

Submit your manuscripts at

www.hindawi.com
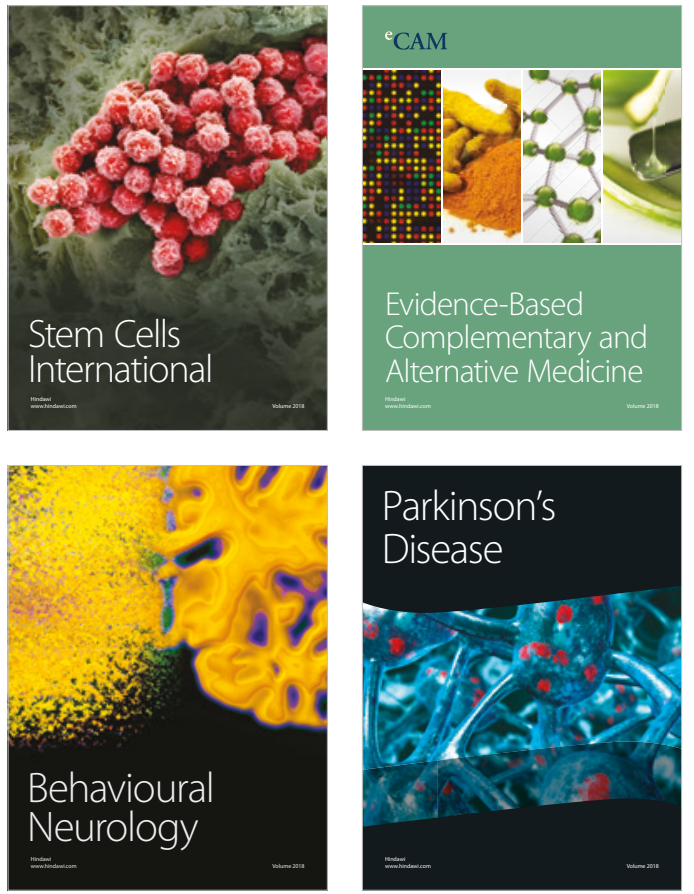

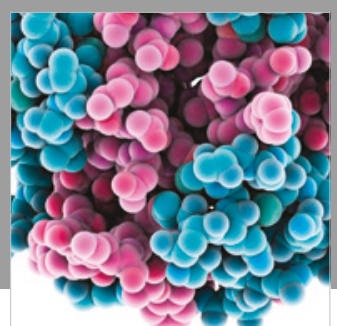

ournal of

Diabetes Research

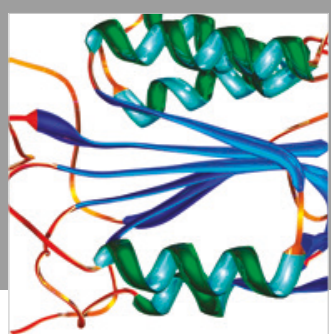

Disease Markers
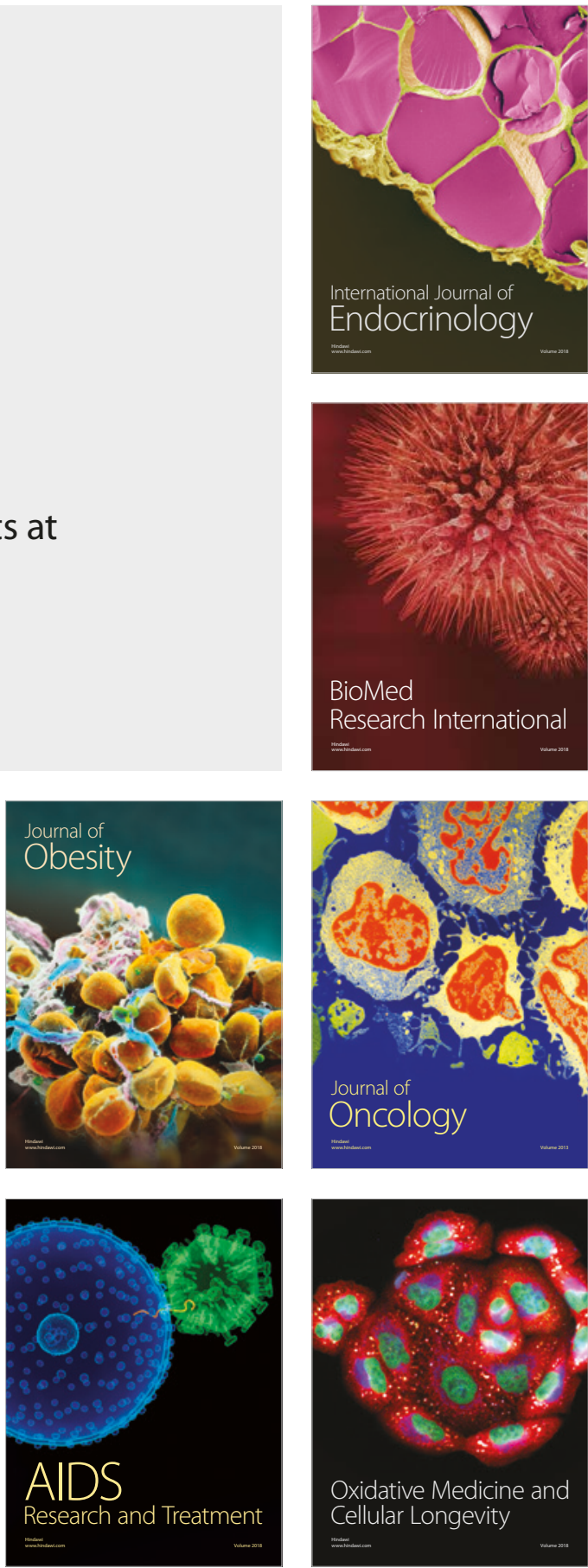